Rhode Island College

Digital Commons @ RIC

Master's Theses, Dissertations, Graduate

Master's Theses, Dissertations, Graduate

Research and Major Papers Overview

Research and Major Papers

$4-30-2020$

\title{
Procalcitonin: Can it impact the length of antimicrobials
}

John Mannino

Follow this and additional works at: https://digitalcommons.ric.edu/etd

Part of the Nursing Commons

\section{Recommended Citation}

Mannino, John, "Procalcitonin: Can it impact the length of antimicrobials" (2020). Master's Theses, Dissertations, Graduate Research and Major Papers Overview. 358.

https://digitalcommons.ric.edu/etd/358

This Major Paper is brought to you for free and open access by the Master's Theses, Dissertations, Graduate Research and Major Papers at Digital Commons @ RIC. It has been accepted for inclusion in Master's Theses, Dissertations, Graduate Research and Major Papers Overview by an authorized administrator of Digital Commons @ RIC. For more information, please contact digitalcommons@ric.edu. 


\section{PROCALCITONIN}

CAN IT IMPACT THE NUMBER OF DAYS A SEPTIC PATIENT IS EXPOSED TO ANTIMICROBIALS?

by

John Mannino BSN, RN, CCRN

A Major Paper Submitted in Partial Fulfillment of the Requirements for the Degree of

Master of Science in Nursing

in

The School of Nursing

Rhode Island College

2020 


\begin{abstract}
The purpose of this project was to conduct a systematic review to assess if using procalcitonin levels to guide antimicrobial therapy has an impact on the number of days an adult septic patient is exposed to antimicrobial therapy. Bacterial resistance is a problem encountered throughout the world. Prolonged exposure is a factor contributing to widespread bacterial resistance. Sepsis is a condition requiring administration of antimicrobials that are often continued despite signs of infection. Many biomarkers are being investigated to facilitate a providers' decision to discontinue antimicrobial therapy in the septic patient. Procalcitonin is a biomarker at the forefront of research to accommodate this decision.

Data tables and a cross-study analysis was conducted to research the primary outcome of total days a septic patient received antimicrobial therapy in a procalcitonin treatment group versus traditional empiric antimicrobial therapy. The secondary outcome was the effect of both groups on mortality rates.
\end{abstract}

All studies showed a reduction of days a septic patient received antimicrobials. Three of the five studies concluded there was a reduction of days a septic patient received antimicrobials. All studies showed a clinically significant decrease of days a septic received antimicrobials without an increase in mortality. The RCTs included in this systematic review investigated procalcitonin's role in small sample sizes making generalization difficult. Procalcitonin may be used in conjunction with other biomarkers to guide antimicrobial therapy in the septic patient. Advance Practice Registered Nurses may utilize this review in providing education and training to peers regarding the use of procalcitonin in the septic patient. 


\section{Table of Contents}

Background/Statement of the Problem .......................................................................

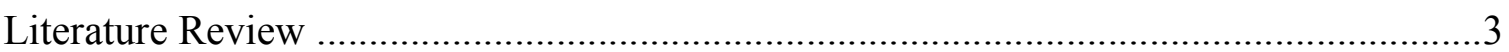

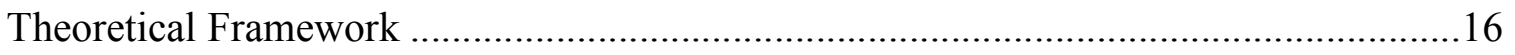

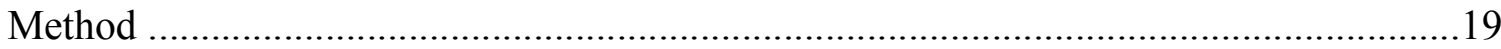

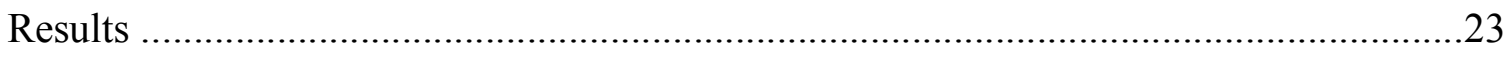

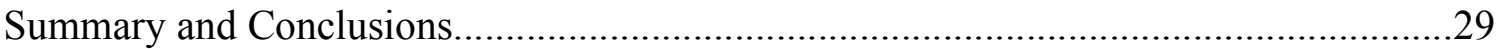

Recommendations and Implications for Advanced Nursing Practice ............................34

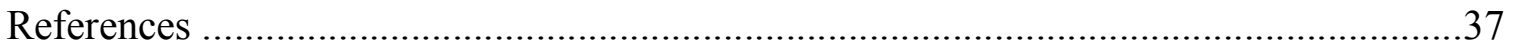

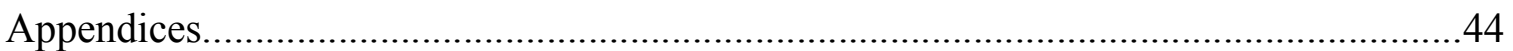




\section{Procalcitonin}

Can it Impact the Number of Days a Septic Patient is Exposed to Antimicrobials?

\section{Background/Statement of the Problem}

Sepsis is defined as a "life-threatening organ dysfunction caused by a dysregulated host response to infection" (Marik \& Taeb, 2017, p. 943). Early recognition and treatment of infection is the goal of care. Broad spectrum antimicrobials are administered until further identifying the source of infection. This method of administration contributes to the overall length of time a patient is exposed antimicrobials.

Bacterial resistance to antimicrobials is a proven threat to world health (Lior \& Bjerrum, 2014). Bacteria utilize mechanisms which help them evolve becoming increasingly resistant to antimicrobials. Evolution is creating multidrug-resistant organisms (MDROs) that are nearly immune to a number of available antimicrobials. Multidrug resistant organisms contribute to increased mortality and health care costs. The Center for Disease Control (CDC) estimates approximately twenty billion dollars are attributed to the increased cost and nearly 23,000 people die annually from MDROs (Munita \& Arias, 2016).

Research shows overuse or over prescribing contributes to antimicrobial resistance; in fact, countries prescribing more antimicrobials tend to see higher rates of resistance (Lior \& Bjerrum, 2014). Additional risks associated with overuse of antimicrobials include the increase of severe disease, length of disease, risk of complications, mortality rate, health care costs, and risk of adverse effects (Lior \& Bjerrum) 
Reducing prolonged use of antimicrobials is one way to decrease the time a bacterium is exposed to antimicrobials. Typically, antimicrobials are administered for a specified time according to the type of infection being treated. During the time of administration, the infection may potentially be gone but the use of antimicrobial continues until the predesignated time is reached. Discontinuation of antimicrobials according to the absence of infection may reduce the time a person is exposed to antimicrobials.

Procalcitonin is a biomarker being studied and utilized in medical centers as a guide to initiate, continue, or discontinue antimicrobials. Research exist showing its effectiveness as a biomarker in distinguishing between viral and bacterial infections. The question remains as to whether there is a benefit to using procalcitonin to guide antimicrobial therapy. Can using Procalcitonin levels to guide antimicrobial therapy impact the number of days an adult septic patient is exposed to antimicrobial therapy? The purpose of this systematic review was to assess if using procalcitonin levels to guide antimicrobial therapy has an impact on the number of days an adult septic patient is exposed to antimicrobial therapy.

Next, the literature review will be discussed. 


\section{Literature Review}

\section{Sepsis}

The current definition of sepsis is in its third edition and was created in 2016 by the Surviving Sepsis Campaign (Surviving Sepsis Campaign, n.d.). Sepsis is defined as a "life-threatening organ dysfunction caused by a dysregulated host response to infection" (Marik \& Taeb, 2017, p. 943). Sepsis and septic shock are connected but distinguishable by two factors. The additional presence of hyperlactaemia and concurrent use of vasopressors for treatment defines septic shock (Chausse, Malekele, \& Paruk, 2018). Hyperlactatemia is characterized by a blood level presence of greater than $2 \mathrm{mmol} / \mathrm{L}$. Indiscriminate use of vasopressors does not meet the criteria for septic shock. Administration of vasopressors after failure of fluid resuscitation characterizes vasopressor use when diagnosing septic shock (Chausse et al.).

Incidence and cost. The Centers for Disease Control (CDC) investigated causes of death in the United States of America (USA) from 1999 through 2014. The CDC found approximately 139,000 deaths were attributed to sepsis in 1999; this number was increased by 31\%, to 182,000 deaths in 2014 (Epstein, Dantes, Magill, \& Fiore, 2016). By 2016, the incidence of death per year caused by sepsis in the USA has risen to over 200,000 people (Moore et al., 2016).

Measuring incidence of sepsis is not consistent and sometimes unreliable (Genga $\&$ Russell, 2017). Statistics related to the incidence of sepsis depend on the data being researched. Some of the tools utilized to research the incidence of sepsis include insurance claims, International Classification (ICD) codes, and searching for organ 
dysfunction or infection. Estimates of the incidence of sepsis range from 3 to 10 per 1,000 people annually in industrialized nations (Genga \& Russell).

Health care costs for treatment of sepsis in the USA are rising. Annual hospital admission rates of people with sepsis reach almost one billion people in 2013 (Paoli, Reynolds, Sinka, Gitlin, \& Crouser, 2018). The average daily costs of treatment in 2013 ranged from $\$ 1,800$ to $\$ 3,000$ dollars with an estimated annual cost of $\$ 24$ billion dollars (Paoli et al.).

Pathophysiology. An infection begins with the immune system recognizing a pathogen as foreign and responds locally to the site of infection. The immune system is equipped with pathogen recognition receptors (PRR) allowing them to recognize pathogens as foreign (Chausse et al., 2018). This ability is possible because pathogens display pathogen associated molecular patterns (PAMP). Once the PRR recognizes the PAMP, complexes are formed creating PAMP-PRR complexes (Chausse et al.). The complexes then release cytokines locally causing the inflammatory response. Sepsis begins when the innate immunity responds systematically causing a hyperinflammatory response (Chausse et al.). The hyperinflammatory response consists of cytokine release, endothelial dysfunction, fibrinolysis, and hypercoagulation.

The cytokines respond in two phases (Chausse et al., 2018). The initial phase consists of a pro-inflammatory response. The pro-inflammatory response causes endothelial damage increasing permeability of the vessels leading to increased edema. Additionally, nitric oxide is released due to endothelial damage. Nitric oxide produces a vasodilatory effect on vessels further contributing to edema and vascular permeability 
(Chausse et al.). These cascading events eventually causes a decrease in systemic blood pressure and hypoperfusion.

The second phase is the anti-inflammatory response, which occurs when the innate immune system begins to control the pro-inflammatory response. A prolonged proinflammatory response leads to hypoperfusion of vital organs causing damage. The antiinflammatory response acts as a buffer and decreases the number and function of the circulating monocytes and lymphocytes (Chausse et al., 2018).

Coagulopathies occur because of endothelial damage. Thrombin formation and fibrinolysis are in flux. Natural anticoagulants become depleted as a result of endothelial damage (Esmon, 2005). Depletion of protein C, protein S, and thrombomodulin creates a hypercoagulable state (Chausse et al., 2018).

The results of the pro-inflammatory phase and a hypercoagulable state consequently create an environment for cellular hypoxia and death (Esmon, 2005). Cellular hypoxia may result from hypoperfusion of vital organs or emboli created from the altered coagulation. The damage created in the cells consequently leads to multiorgan dysfunction further adding to the risk of mortality in the setting of sepsis.

Clinical signs and symptoms. Clinical signs of sepsis include signs of insult or infection; along, with organ dysfunction. The initial onset of infection usually presents with classical signs of fever, chills, and an increase or decrease in white blood cells (Vincent, 2016). Additional signs of infection are dependent of the site of infection. For example, an infection of the lungs, or pneumonia, will present with signs consistent with pneumonia. Symptoms may include, but not limited to, fever, shortness of breath, decreased or absent breadth sounds, and productive cough. 
Organ dysfunction must accompany an insult or infection for the diagnosis of sepsis (Surviving Sepsis Campaign website, n.d). Infection alone is not enough to categorize a condition as sepsis, although an infection may progress to sepsis. The associated organ dysfunction excludes any baseline organ dysfunction a person may have previous to infection (Singer et al., 2016). Signs of organ dysfunction depend upon which organ is affected. For example, early signs of renal failure present with oliguria, or low urine output, and an increase in the serum creatinine.

The SSC endorses the use of the Sequential Organ Failure Assessment (SOFA) score to predict signs of organ dysfunction. Originally developed by the ESICM in 1994, the SOFA score is used to quantify signs of organ dysfunction and predict mortality (Nair, Bhandary, \& D'Souza, 2016). From the years 2000 to 2015, a retrospective cohort analysis of 184,000 adults shows the SOFA score was able to discriminate in hospital mortality greater than scoring with systemic inflammatory response syndrome (SIRS) and the quick SOFA score with an area under the receiver operating characteristic curve (AUROC) of 0.753 , confidence interval of $99 \%$, and a probability value of less than 0.001 (Raith, Udy, \& Bailey, 2017). Patients are given a score according to their condition within six categories. The respiratory system is assessed by a score based upon the patients' measured partial pressure of oxygen (Pa02), fraction of inspired air (Fi02), and use of a mechanical ventilator. The hematological system is scored based upon a patient's tested platelet value and the neurological system is measured by scoring a patient according to their presenting Glasgow Coma Scale. Liver function score is based upon receiving the tested bilirubin and the renal system consists of scoring according to their tested serum creatinine. Lastly, the cardiovascular system is scored based on the 
patients' presenting mean arterial pressure (MAP) and/or use of vasoactive medication (Ferreira, Bota, Bross, Melot, \& Vincent, 2001).

Diagnosis. A sepsis diagnosis is considered when a patient presents with signs of an infection and scores two or greater on the SOFA scale (Singer et al., 2016). The onset of fever, chills, tachypnea, and increase or decrease in white blood cells may be the first signs of an infection (Vincent, 2016). The source of infection is not always identified and may appear from any form of pathogen. Bacteria, parasites, viruses, and trauma are examples of conditions that may cause sepsis (Polat, Ugan, Cadirci, \& Halici, 2017). The infection then progresses to create a dysregulated immune response eventually leading to organ dysfunction. The SSC endorses utilizing the SOFA score for assessment of organ dysfunction. A dysregulated immune response and signs of organ dysfunction categorize sepsis (Surviving Sepsis Campaign, n.d.) Organ dysfunction must accompany an infection prior to being diagnosed with sepsis.

\section{Sepsis Treatment}

In 2002, The Society of Critical Care Medicine (SCCM) and the European Society of Intensive Care Medicine (ESICM) convened to develop the Surviving Sepsis Campaign (SSC). The SSC's mission is to "reduce mortality and morbidity from Sepsis and Septic shock worldwide" (Surviving Sepsis Campaign, n.d., para 1). The SSC has transformed the way health care providers view and treat sepsis and aims to reduce mortality by making health care providers and the public aware of sepsis. The founders have campaigned diligently, utilizing research and seminars, to spread the message about sepsis. The SSC continues to research and provide recommendations for treatment. 
The Surviving Sepsis Campaign first published guidelines for early recognition and treatment in 2004 (Surviving Sepsis Campaign, n.d.). Guidelines have continued to evolve through the years. The second edition was accepted by 28 countries in 2008 . In 2012, the third edition included the term International. The pinnacle arrived in 2013 , when the United States of America's (USA) regulatory bodies required treatment of sepsis according to the published guidelines (Surviving Sepsis Campaign website). The latest guidelines are in the fourth edition and were published in 2016 with an update in 2018 (Surviving Sepsis Campaign).

The SSC guideline (2018) includes a one-hour bundle. The one-hour bundle signifies the goal of early recognition and treatment. Identifying the source of sepsis aids in the treatment. The SSC endorses locating and identifying the cause of sepsis to adequately provide treatment. Causes of sepsis may arise from noninfectious states, such as trauma or pancreatitis. Other causes of sepsis may result from bacterial, fungal, parasitic, or viral infections (Polat et al., 2017). The SSC emphasizes the goal of one hour to encourage providers to act quickly in identifying and beginning early treatment for sepsis (Surviving Sepsis Campaign, n.d.). The clock starts from the time sepsis is identified. The bundle includes obtaining aerobic and anaerobic blood cultures before administration of antimicrobials, administration of broad spectrum antimicrobials, measurement of lactate, rapid infusion of $30 \mathrm{ml} / \mathrm{kg}$ of crystalloid fluids for hypotension or a lactate greater than $4 \mathrm{mmol} / \mathrm{L}$, and application of vasoactive medications for hypotension during or after fluid resuscitation for maintenance of a MAP of greater than $65 \mathrm{~mm} \mathrm{Hg}$ (Levy, Evans, \& Rhodes, 2018). The one-hour bundle goals are illustrated in Table 1 on the next page. 
Table 1 One-Hour Sepsis Bundle

\begin{tabular}{|l|l|}
\hline 1 & Measure lactate level \\
\hline 2 & Obtain blood cultures before administering antimicrobials \\
\hline 3 & Administer broad-spectrum antimicrobials \\
\hline 4 & $\begin{array}{l}\text { Begin rapid administration of } 30 \mathrm{ml} / \mathrm{kg} \text { crystalloid for hypotension or lactate less than } \\
4 \mathrm{mmol} / \mathrm{L}\end{array}$ \\
\hline 5 & $\begin{array}{l}\text { Apply vasopressors if hypotensive during or after fluid resuscitation to maintain a mean } \\
\text { arterial pressure greater than } 65 \mathrm{mmHg} .\end{array}$ \\
\hline
\end{tabular}

(Surviving Sepsis Campaign, n.d.)

The SSC makes additional recommendations within its 2016 guidelines. Empiric broad spectrum combination therapy with antimicrobials are recommended until the offending pathogen is discovered and the antimicrobial spectrum can be narrowed (Society of Critical Care Medicine \& European Society of Intensive Care Medicine, 2016). Blood cultures should be obtained prior to administration of antimicrobials but obtaining cultures should not delay antimicrobial administration. Sepsis-induced hypotension, or a MAP less than $65 \mathrm{mmHg}$, should first be treated with crystalloids as the fluid of choice within the first three hours of suspected sepsis. The guidelines endorse reevaluation of the hemodynamic status continuously and administration of additional fluids may be warranted based upon the patient's status (Society of Critical Care Medicine and European Society of Intensive Care Medicine). Serum lactate levels should be assessed and used to guide fluid resuscitation efforts. Serum lactate levels $>4 \mathrm{mmol} / \mathrm{L}$ indicates tissue hypoperfusion in the state of sepsis (Surviving Sepsis Campaign, n.d.). The guidelines explicitly state a target MAP of $65 \mathrm{mmHg}$ and recommend the use of vasopressors with or after initial fluid administration. Norepinephrine is the vasopressor 
of choice with addition of vasopressin if the patient's condition warrants a second vasopressor. The guidelines further suggest assessing cardiac function if the patient's hemodynamic status has not improved with the use of vasopressors (Society of Critical Care Medicine and European Society of Intensive Care Medicine, 2016). The guidelines also endorse assessing glucose levels frequently and maintaining the glucose level less than $180 \mathrm{mg} / \mathrm{dL}$. Nutritional support is recommended by the guidelines and they advocate for the use of enteral feedings above all nutritional support options (Society of Critical Care Medicine and European Society of Intensive Care Medicine).

\section{Antimicrobials}

Antimicrobial is a general term for medications with specific actions against infections (Leekha, Terrell, \& Edson, 2011). The term antimicrobials include medications with antifungal, antibacterial, antiviral, and antiparasitic properties (Leekha et al.). Each antimicrobial has a specific action to combat different species of bacteria. Broad spectrum antimicrobials contain activity against multiple types and species of bacteria. Broad spectrum antimicrobials are administered until a source of infection is discovered and the bacteria is identified through culture. Antimicrobials are then changed according to the sensitivity of the bacteria isolated (Roca et al., 2015).

The 'empiric use' of antimicrobials involves when clinicians prescribe antimicrobials without definitive diagnosis of an infection (Michael, Dominey-Howes, \& Labbate, 2014). The patient presents with signs of an infection, but the provider is unable to identify the source or species of the causative agent. Diagnostic tests can take a few days to a week to identify the bacterial species. Therefore, empiric use of antimicrobials 
prolong the patient's overall exposure to antimicrobials and may lead to unwanted complications or side effects from the medication (Lior \& Bjerrum, 2014).

The use of antimicrobials indiscriminately can have an effect on patients. Patients may suffer from unwanted side effects which may include, but are not limited to, nausea, vomiting, diarrhea, and headache. Administration of antimicrobials also place patients at risk for adverse drug reactions (ADRs). Adverse drug reactions account for nearly 6 percent of hospital admissions and occur in approximately 10-15\% of hospitalized patients (Thong \& Seng, 2010) and include life threatening skin conditions organ damage, and organ failure.

Widespread usage of antimicrobials has led to bacterial resistance. Antimicrobials were once very effective in treating bacterial infections. Widespread use and time have contributed to certain strains of bacteria evolving and becoming resistant to antimicrobials (Michael et al., 2014). For example, methicillin-resistant Staphylococcus aureus (MRSA) is a specific strain of Staphylococcus aureus previously treated routinely with an antimicrobial named methicillin. Over time, the bacteria have evolved and became resistant to methicillin. Today, MRSA is considered a MDRO and, "kills more Americans every year than emphysema, HIV, AIDS, Parkinson's disease and homicide combined" (Lior \& Bjerrum, 2014, p. 229). The prevalence of MDROs are increasing in society.

Septic treatment involves the use of antimicrobials. Utilizing a practice of deescalation or discontinuing antimicrobials according to diagnostic criteria may reduce a person's exposure, thus reducing a chance for the bacteria to develop resistance. In 2013, Silva, Atallah, and Salomao conducted a systematic review exploring de-escalation of 
antimicrobials in the septic adult patient. Their initial search results yielded 493 studies, none of which were randomized control trials (RCTs). The authors concluded current research was insufficient for evaluating their hypothesis. They were successful in providing a review for possible future studies into de-escalation practices for reducing antimicrobial exposure to reduce bacterial resistance (Silva et al.).

\section{Biomarkers}

Biomarkers objectively measure a biological response to illness or intervention (Biron, Ayala, \& Lomas-Neira, 2015). Biomarkers may take the form of any measurement that shows a biological process and can influence or show the effects of treatment (Strimbu \& Tavel, 2010). Biomarkers are being investigated to determine the best way to predict and treat sepsis. Most investigations surround the use of serum blood test in identifying biomarkers that may be increased or decreased in the presence of sepsis. Current investigations include initiating and discontinuing antimicrobial therapy relative to the blood concentration of the biomarkers. Biomarkers being investigated include pro-inflammatory cytokines and C-Reactive Protein (CRP), with Procalcitonin (PCT) being the primary one being investigated (Biron, Ayala, \& Lomas-Neira, 2015).

Pro-inflammatory cytokines. The innate immune system includes the human body's ability to recognize and attack pathogens through a system of actions (Alberts et al., 2002). These actions may include an inflammatory response and phagocytosis (Alberts et al.). Pro-inflammatory cytokines include Tumor Necrosis Factor (TNF), Interleukin $1 \beta$ (IL-1 $\beta$ ) and Interleukin 6 (IL-6) and they are released to initiate the innate immune response. Investigations have revealed unreliability in testing serum TNF and IL- $1 \beta$ but plasma levels of IL- 6 are more consistent and reliable to test as an 
inflammatory marker (Faix, 2013). Studies investigating IL-6 have concluded that IL-6 is better utilized as a prognostic tool rather than a diagnostic tool. Subsequently, increased levels of IL-6 are associated with an increase in mortality in people diagnosed with sepsis (Faix, 2013).

C-reactive protein. C-Reactive Protein is a protein produced in the liver and upregulated by IL-6 during phases of inflammation (Faix, 2013). C-reactive protein has been investigated but its specificity to sepsis is low because it indicates inflammation rather than infection. The specificity of testing CRP is too low to be diagnostic for sepsis (Biron, Ayala, \& Lomas-Neira, 2015).

\section{Procalcitonin}

There are two cell types in the human thyroid. The follicular cells produce the thyroid hormones and the parafollicular cells or $\mathrm{C}$ cells produce calcitonin (Cote, Grubbs, \& Hofmann, 2015). Procalcitonin is produced by the C cells of the thyroid and is a precursor to the hormone Calcitonin (Davies, 2015). During normal health, procalcitonin is changed into calcitonin in the thyroid and cannot change in any other tissue limiting its systemic blood concentration. During times of infection, all parenchymal tissue release procalcitonin causing systemic concentrations to rise above the naturally occurring less than $0.05 \mathrm{ng} / \mathrm{L}$ (Davies, 2015). Procalcitonin is down-regulated during viral infection and upregulated during bacterial infection. Up and down regulation may be useful in guiding antimicrobial therapy in a septic patient.

In a large prospective study based in 13 U.S. ICU's (Schuetz et al., 2017), 858 subjects were enrolled in a trial focused on assessing 28-day mortality among sepsis patients. The authors were investigating if reducing procalcitonin levels by $80 \%$ through 
a period of five days impacted the mortality rate among subjects with sepsis. Schuetz et al. found the 28-day all-cause mortality was two times greater in subjects who did not show an $80 \%$ decrease in Procalcitonin levels at five days from baseline, $20 \%$ versus $10 \%$ with a probability value of 0.001 . The group with a decrease of less than $80 \%$ included 413 patients, 83 succumbed to mortality while 330 patients were alive at 28 days. The group with a decrease of greater than $80 \%$ included 233 patients, 24 died and 209 survived 28 days (Schuetz et al.).

A systematic review (Schuetz, Briel, \& Mueller, 2013) investigated if measuring procalcitonin to guide antimicrobial therapy reduced antimicrobial exposure without an increase in mortality. The review revealed a total of 14 trials of adult patients diagnosed with respiratory infections. Of the 14 , two were in primary care, seven in the emergency department (ED), and five were conducted in the ICU setting in various countries throughout the world. The studies occurred between 2004-2011. The authors explained the results from the trials conducted in the ED and ICU. Subjects from the ED trials received treatment with antimicrobials according to procalcitonin levels for a mean of 7 days versus 10 days without the use of procalcitonin to guide their antimicrobial therapy. Subjects from the ICU trials received treatment with antimicrobials according to procalcitonin levels for a mean of 8 days compared to 12 days without the use of procalcitonin levels. Of all 14 trials, 118 patients experienced mortality in the procalcitonin group compared to 134 patients in the control group. Antimicrobial exposure time was 4 days in the procalcitonin group versus 8 days in the control group. The authors concluded using procalcitonin to guide antimicrobial therapy reduced the time of exposure without increasing mortality (Schuetz et al). 
Sepsis recognition and treatment are evolving. Antimicrobial administration is paramount in treating infectious causes of sepsis. How long should antimicrobials continue once the infection has ceased? Finding a diagnostic tool to assist in continuing or discontinuing antimicrobial administration may reduce exposure to antimicrobials. Reducing exposure may lead to a decreased prevalence of bacterial resistance. Thus, the question remains, can using procalcitonin levels to guide antimicrobial therapy impact the number of days an adult septic patient is exposed to antimicrobial therapy?

Next, the theoretical framework will be discussed. 


\section{Theoretical Framework}

Evidence-based practice (EBP) is at the forefront of health care. It has paved the way to new forms of research within the health care community. Systematic reviews stem from the desire to synthesize the mounting evidence produced by EBP (Daley, 2016). Today, systematic reviews are utilized to change practice and formulate guidelines according to collected evidence (Moher, Liberati, Tezlaff, \& Altman, 2009).

In 2009, the Preferred Reporting Items for Systematic Reviews and Meta-analyses (PRISMA) was established (Daley, 2016). Preferred Reporting Items for Systematic Reviews and Meta-analyses was created to objectively analyze, write, and assess validity of research contained within systematic reviews. Preferred Reporting Items for Systematic Reviews and Meta-analyses also contains a flow diagram enabling the researcher to identify, organize, structure, and develop the search for evidence included into a systematic review (Figure 1). The flow diagram takes the author through steps of identifying relevant articles, screening abstracts for inclusion criteria, assessing full text articles based on eligibility, and then documenting included and excluded articles utilized for the systematic review (Liberati et al., 2009). 


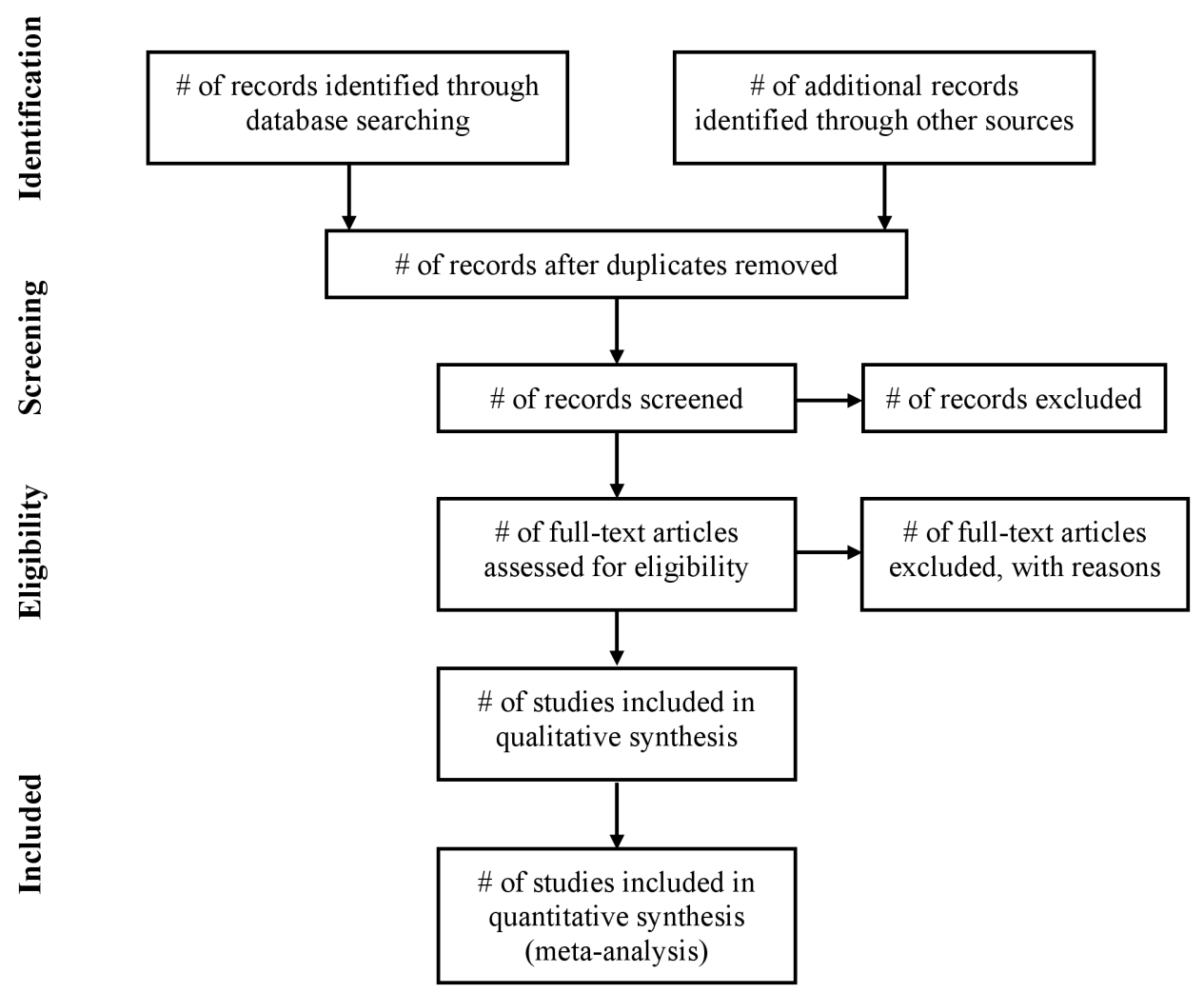

Figure 1. PRISMA flow diagram. This figure illustrates the PRISMA flow diagram (Liberati et al).

Preferred Reporting Items for Systematic Reviews and Meta-analyses includes a twenty-seven-point checklist, with seven categories, to evaluate research (Figure 2). The checklist allows for objectively evaluating research to include within a systematic review. It enables organization of studies and allows the researcher to appraise the research (Moher et al., 2009). Preferred Reporting Items for Systematic Reviews and Metaanalyses and the PRISMA flow diagram will be utilized to organize and objectively evaluate research for inclusion of the systematic review. 


\begin{tabular}{|c|c|c|c|}
\hline Section/Topic & \# & Checklist Item & Reported on Page \# \\
\hline \multicolumn{4}{|l|}{ TITLE } \\
\hline Title & 1 & Identify the report as a systematic review, meta-analysis, or both. & \\
\hline \multicolumn{4}{|l|}{ ABSTRACT } \\
\hline Structured summary & 2 & $\begin{array}{l}\text { Provide a structured summary including, as applicable: background; objectives; data sources; study eligibility } \\
\text { criteria, participants, and interventions; study appraisal and synthesis methods; results; limitations; conclusions } \\
\text { and implications of key findings; systematic review registration number. }\end{array}$ & \\
\hline \multicolumn{4}{|l|}{ INTRODUCTION } \\
\hline Rationale & 3 & Describe the rationale for the review in the context of what is already known. & \\
\hline Objectives & 4 & $\begin{array}{l}\text { Provide an explicit statement of questions being addressed with reference to participants, interventions, } \\
\text { comparisons, outcomes, and study design (PICOS). }\end{array}$ & \\
\hline \multicolumn{4}{|l|}{ METHODS } \\
\hline Protocol and registration & 5 & $\begin{array}{l}\text { Indicate if a review protocol exists, if and where it can be accessed (e.g., Web address), and, if available, provide } \\
\text { registration information including registration number. }\end{array}$ & \\
\hline Eligibility criteria & 6 & $\begin{array}{l}\text { Specify study characteristics (e.g., PICOS, length of follow-up) and report characteristics (e.g., years considered, } \\
\text { language, publication status) used as criteria for eligibility, giving rationale. }\end{array}$ & \\
\hline Information sources & 7 & $\begin{array}{l}\text { Describe all information sources (e.g., databases with dates of coverage, contact with study authors to identify } \\
\text { additional studies) in the search and date last searched. }\end{array}$ & \\
\hline Search & 8 & $\begin{array}{l}\text { Present full electronic search strategy for at least one database, including any limits used, such that it could be } \\
\text { repeated. }\end{array}$ & \\
\hline Study selection & 9 & $\begin{array}{l}\text { State the process for selecting studies (i.e., screening, eligibility, included in systematic review, and, if applicable, } \\
\text { included in the meta-analysis). }\end{array}$ & \\
\hline Data collection process & 10 & $\begin{array}{l}\text { Describe method of data extraction from reports (e.g., piloted forms, independently, in duplicate) and any } \\
\text { processes for obtaining and confirming data from investigators. }\end{array}$ & \\
\hline Data items & 11 & $\begin{array}{l}\text { List and define all variables for which data were sought (e.g., PICOS, funding sources) and any assumptions and } \\
\text { simplifications made. }\end{array}$ & \\
\hline $\begin{array}{l}\text { Risk of bias in individual } \\
\text { studies }\end{array}$ & 12 & $\begin{array}{l}\text { Describe methods used for assessing risk of bias of individual studies (including specification of whether this was } \\
\text { done at the study or outcome level), and how this information is to be used in any data synthesis. }\end{array}$ & \\
\hline Summary measures & 13 & State the principal summary measures (e.g., risk ratio, difference in means). & \\
\hline Synthesis of results & 14 & $\begin{array}{l}\text { Describe the methods of handling data and combining results of studies, if done, including measures of } \\
\left.\text { consistency (e.g., }\left.\right|^{2}\right) \text { for each meta-analysis. }\end{array}$ & \\
\hline Risk of bias across studies & & $\begin{array}{l}\text { Specify any assessment of risk of bias that may affect the cumulative evidence (e.g., publication bias, selective } \\
\text { reporting within studies). }\end{array}$ & \\
\hline Additional analyses & 16 & $\begin{array}{l}\text { Describe methods of additional analyses (e.g., sensitivity or subgroup analyses, meta-regression), if done, } \\
\text { indicating which were pre-specified. }\end{array}$ & \\
\hline \multicolumn{4}{|l|}{ RESULTS } \\
\hline Study selection & 17 & $\begin{array}{l}\text { Give numbers of studies screened, assessed for eligibility, and included in the review, with reasons for exclusions } \\
\text { at each stage, ideally with a flow diagram. }\end{array}$ & \\
\hline Study characteristics & 18 & $\begin{array}{l}\text { For each study, present characteristics for which data were extracted (e.g., study size, PICOS, follow-up period) } \\
\text { and provide the citations. }\end{array}$ & \\
\hline Risk of bias within studies & s19 & Present data on risk of bias of each study and, if available, any outcome-level assessment (see Item 12). & \\
\hline $\begin{array}{l}\text { Results of individual } \\
\text { studies }\end{array}$ & 20 & $\begin{array}{l}\text { For all outcomes considered (benefits or harms), present, for each study: (a) simple summary data for each } \\
\text { intervention group and (b) effect estimates and confidence intervals, ideally with a forest plot. }\end{array}$ & \\
\hline Synthesis of results & 21 & Present results of each meta-analysis done, including confidence intervals and measures of consistency. & \\
\hline Risk of bias across studies & 522 & Present results of any assessment of risk of bias across studies (see Item 15). & \\
\hline Additional analysis & 23 & Give results of additional analyses, if done (e.g., sensitivity or subgroup analyses, meta-regression [see Item 16]). & \\
\hline \multicolumn{4}{|l|}{ DISCUSSION } \\
\hline Summary of evidence & 24 & $\begin{array}{l}\text { Summarize the main findings including the strength of evidence for each main outcome; consider their } \\
\text { relevance to key groups (e.g., health care providers, users, and policy makers). }\end{array}$ & \\
\hline Limitations & 25 & $\begin{array}{l}\text { Discuss limitations at study and outcome level (e.g., risk of bias), and at review level (e.g., incomplete retrieval of } \\
\text { identified research, reporting bias). }\end{array}$ & \\
\hline Conclusions & 26 & $\begin{array}{l}\text { Provide a general interpretation of the results in the context of other evidence, and implications for future } \\
\text { research. }\end{array}$ & \\
\hline \multicolumn{4}{|l|}{ FUNDING } \\
\hline Funding & 27 & $\begin{array}{l}\text { Describe sources of funding for the systematic review and other support (e.g., supply of data); role of funders for } \\
\text { the systematic review. }\end{array}$ & \\
\hline
\end{tabular}

Figure 2. The PRISMA checklist. This figure illustrates the PRISMA checklist for evaluation of research (Liberati et al., 2009).

Next, the method utilized for this systematic review will be discussed. 


\section{Method}

\section{Purpose and Research Question}

The purpose of the project was to conduct a systematic review investigating the use of procalcitonin to guide antimicrobial therapy in the setting of sepsis.

The research question: Does using procalcitonin levels to guide antimicrobial therapy impact the number of days an adult septic patient is exposed to antimicrobial therapy?

\section{Search Strategy}

Online databases were searched using keywords. Search words included sepsis, procalcitonin, antibiotics and antimicrobials, adults, and intensive care unit, critical care unit, or ICU. The databases chosen included Google Scholar, Medline, Ovid, and Pubmed. The PRISMA flow diagram was used to document the search path utilized to conduct the systematic review.

\section{Inclusion Criteria}

Inclusion criteria consisted of RCTs conducted between the years of 2004 to 2019. Adult patients, from ages 18 through 85 years old, were included in the search. Adults must meet the definition of sepsis as defined by the Surviving Sepsis Campaign: a "life-threatening organ dysfunction caused by a dysregulated host response to infection" (Marik \& Taeb, 2017, p. 943). Subjects must be receiving antimicrobial treatment in the intensive care unit (ICU) setting. Procalcitonin levels are required in the treatment group and must be integrated to guide antimicrobial therapy. All articles are full text and written in the English language. 


\section{Exclusion Criteria}

Exclusion criteria included articles in languages other than English, non-peerreviewed journals, and duplicate studies, pediatric patient population defined as 17 years or younger, and patients not hospitalized in the ICU. Additionally, studies not defined as RCTs and RCTs not using a procalcitonin algorithm will be excluded.

\section{Data Collection}

Data were collected and analyzed utilizing tables created by the author. Key information was extracted from RCTs and labeled within the tables. The first table (Table 2 below) identified the following: source of study, purpose of study, study design/setting, sample, and method utilized. This enabled the author to identify and appraise elements of RCTs to be included within the systematic review.

Table 2

\section{Data Collection Tool 1}

\begin{tabular}{|c|c|c|c|c|}
\hline Source & Purpose & $\begin{array}{c}\text { Study } \\
\text { Design/Setting }\end{array}$ & Sample & Method \\
\hline & & & & \\
\hline
\end{tabular}

A second collection tool was used to detail the methods utilized by the researchers and the results of the study. The table included information pertaining to the specific procalcitonin algorithm utilized during the study. Next, the total number of days a patient received antimicrobial therapy was assessed. In Table 3 on the next page, a comparison is shown between the total number of days subjects received antimicrobial therapy based upon a procalcitonin algorithm and those in the control group not receiving treatment based upon a procalcitonin algorithm. 


\section{Table 3}

\section{Data Collection Tool 2}

\begin{tabular}{|c|c|c|c|}
\hline \multicolumn{2}{|c|}{ Treatment Methods } & Total Days Receiving Antimicrobials & \multirow{2}{*}{ Results } \\
\cline { 1 - 2 } $\begin{array}{c}\text { Intervention } \\
\text { Group }\end{array}$ & Control Group & $\begin{array}{c}\text { Intervention } \\
\text { Group }\end{array}$ & Control Group \\
\end{tabular}

\section{Appraisal}

The Critical Appraisal Programme (CASP) is integral to evaluate RCTs and provides a systematic framework to assess the integrity and validity of a RCT. The CASP is comprised of 11 questions, with the first three questions used as a filter before moving onto the subsequent questions (CASP checklist, 2019). The first three questions decipher if the trial addresses a clearly focused issue, if patients were assigned to the trial randomly, and if all patients accounted for in the conclusion. The answer to the first three questions must be "yes" before moving forward with the CASP. If the first three questions illicit a "no" response, the validity of the RCT may be in question. The CASP checklist is an additional tool that was used to evaluate the quality of RCTs (Appendix C).

\section{Cross Study Analysis}

The RCTs were compared with a cross study analysis. Tables were specially designed by the author to summarize the individual findings of each RCTs. A cross study analysis was performed by comparing the individual results with each other to further identify commonalties and/or difference across all studies. Data were analyzed for decreased utility of antimicrobials based upon using a procalcitonin algorithm. Therefore, the cross study focused on comparing the treatment group versus a control group, 
whereas, the control group received antimicrobial therapy without the use of a procalcitonin algorithm. 


\section{Results}

Google Scholar, Ovid, Pubmed, and Medline online databases were searched with the following key words; sepsis, procalcitonin, antibiotics or antimicrobials, adults, and intensive care unit or critical care unit or ICU. The initial search identified 1,920 articles. Further screening for duplicate and full text articles yielded 72 results. The articles remaining were screened for eligibility producing 28 results. Of the 28 results, 5 RCTs were chosen for inclusion of this systematic review.

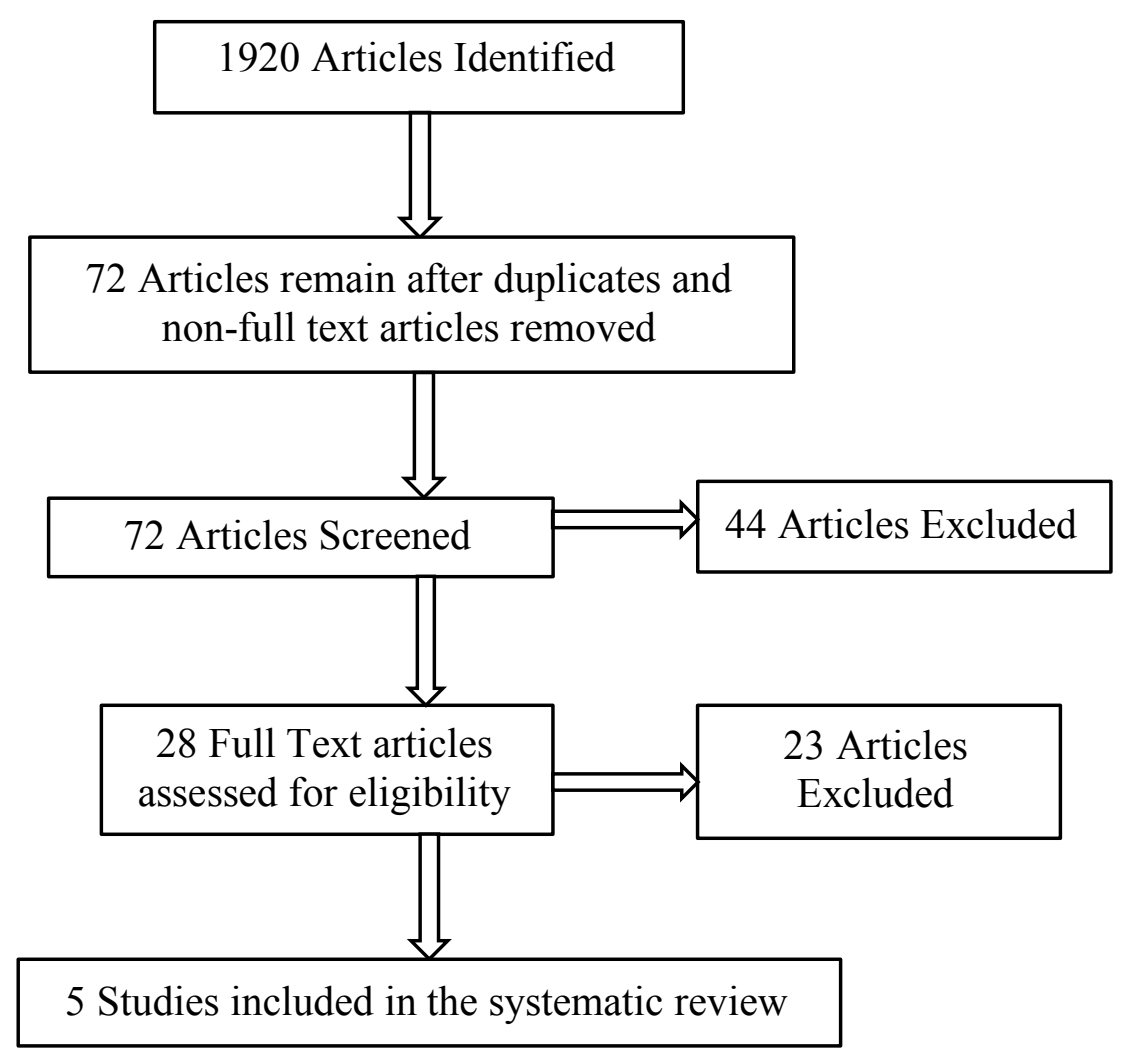

Figure 1. PRISMA flow diagram. This figure illustrates the screening and eligibility of articles utilized for this systematic review 
Nobre, Harbath, Graf, Rohner, \& Pugin conducted a RCT (Appendix A - 1) to investigate if following procalcitonin levels to guide antimicrobial therapy in suspected or confirmed sepsis or septic shock impacted the number of days a patient received antimicrobials (2008). The study included a total of 68 patients after screening for inclusion and exclusion criteria. The primary outcome measured was the duration of antimicrobials a patient received. The secondary outcome measured was the 28-day mortality.

Nobre et al. measured the median antimicrobial duration for the first episode of infection, total antimicrobial exposure days, and days alive without antimicrobials (Appendix B - 1) (2008). The median duration of antimicrobial therapy for the first episode of infection reached a median time of 10 days in the control group and six days in the procalcitonin group with a statistically significant probability (p) value of 0.003 and a 95\% confidence interval. Total antimicrobial exposure, measured as median days, reached 655 in the control group and 504 in the procalcitonin groups $(p=0.0002)$. Total days alive without antimicrobials resulted in 13.6 days and 17.4 days in the control and procalcitonin group respectively. The secondary outcome studied the 28-day mortality. The investigators showed a 28-day mortality of six patients in the control group and five patients in the procalcitonin group or $16.2 \%$ in both groups with a probability value of 0.74. Nobre et al. demonstrated a shorter median ICU LOS was reached in the procalcitonin group, three days vs five days in the control group with clinical significance $(p=0.03)$. The critical analysis of Nobre et al. (2008) is illustrated in Appendix C -1 . The analysis demonstrated that Nobre et al. conducted a sound randomized control trial. Patients were randomized and blinded to the study. 
Some limitations existed in the study. The trial consisted of a low study population of 68 patients at a single center. The small sample size cannot effectively be distributed to represent the general population. The number of dropouts occurring during the trial was disproportionate between the procalcitonin and control group ( 8 vs $3, p=$ 0.197). Difficult to treat organisms were not included in the study for safety reasons and empiric rules guiding antimicrobial therapy were utilized (Nobre et al.).

The second article (Appendix A - 2) investigated if utilizing procalcitonin levels to guide antimicrobial therapy in surgical intensive care patients suffering from severe sepsis decreased the total duration of receiving antimicrobials (Schroeder et al., 2008). The RCT includes 14 patients after screening for inclusion and exclusion criteria. The investigators ceased antimicrobials if a patient's procalcitonin level reached $<1 \mathrm{ng} / \mathrm{ml}$ or a decrease of $30 \%$ by day three from the original sampling. Schroeder et al. found the mean days of receiving antimicrobials were 6.6 in the procalcitonin group and 8.3 in the control group $(\mathrm{p}<0.001)$ (Appendix B - 2). Schroeder et al. showed a decrease in antimicrobial therapy days while utilizing procalcitonin levels to guide therapy. The critical analysis is illustrated in Appendix C - 2 and it is unclear whether the patients and investigators were blinded due to insufficient information presented in the study. This study only included a total of 14 patients and did not investigate the effect of the study on mortality rates.

Annane et al. (Appendix A - 3) investigated the use of procalcitonin levels in directing antimicrobial treatment in critically ill patients with undifferentiated sepsis (2013). The multicentered RCT was conducted over a three-year period and involved 53 patients meeting inclusion and exclusion criteria. A total of 53 patients were randomized to either a procalcitonin based antimicrobial therapy guideline or empiric antimicrobial 
guidelines. The primary outcome measured was the comparative number of patients receiving antimicrobials on day five. Secondary outcomes measured included mortality at day five, at ICU discharge, and at hospital discharge (Annane et al.).

Annane et al. (Appendix B - 3) concluded there were 21 patients receiving antimicrobial therapy on day five in the control group and 18 patients in the procalcitonin group $(p=0.24)(2013)$. There were no observed days in either group that were antimicrobial free by day five. The mortality rate on day five was equal among the groups at $10 \%$. The mortality rate by ICU discharge reached $33 \%$ in the control group and $23 \%$ in the procalcitonin group. Although the authors concluded there were less patients on antimicrobials on day five in the procalcitonin group, the findings were not clinically significant $(\mathrm{p}=0.24)$. The study did demonstrate an overall reduction in mortality rate by ICU discharge in the procalcitonin group $(\mathrm{p}=0.40)$. The critical analysis of Annane et al., as shown in Appendix $\mathrm{C}-3$, demonstrates a well completed randomized control study.

A noted limitation of the study was physician non-compliance adherence of drawing procalcitonin levels in the experimental group. Non-compliance in the procalcitonin group reached $19 \%$. Physician non-compliance was also seen with discontinuation of antimicrobials based on procalcitonin levels.

The fourth article included in this systematic review is a prospective observational control study (Appendix A - 4). Bishop et al. investigated if introducing procalcitonin levels to a teaching hospital would reduce the number of days a septic patient was exposed to antimicrobials (2014). The primary outcome was considered to be the total duration of antimicrobial exposure from initiation to discontinuation. Patients were 
compared to historical data of patients with the same demographics, variables, and severity of illness. The secondary outcome considered was the length of hospital stay and 30-day mortality rates. The study included a total of 100 patients, 50 in each group.

The average duration of antimicrobial therapy (Appendix B - 4), measured in average days, was 13.3 in the control group compared to 10 in the procalcitonin group (p $=0.0238$ ) (Bishop et al., 2014). The average length of stay (LOS) in hospital was measured as 17.8 and 13.5 in the control group versus the procalcitonin group respectively $(\mathrm{P}=0.0299)$. Length of stay in ICU averaged 12 days in the control group compared to 8.4 days in the procalcitonin group $(\mathrm{P}=0.0767)$. Furthermore, 30-day mortality reached two $(4 \%)$ patients in the control group and one $(2 \%)$ in the procalcitonin group (Bishop et al.). The critical appraisal of Bishop et al. is provided in Appendix $\mathrm{C}-4$. The investigators executed a well-developed study.

Shehabi et al. conducted a multicenter, prospective, single blind, randomized control trial investigating the impact of a low serum procalcitonin level cutoff for antimicrobials in the suspected or confirmed septic patient (Appendix A - 5) (2014). A total of 394 patients were randomized and included in the trial. The primary outcome measured was the time of discontinuation of antimicrobial therapy at day 28 , death, or hospital discharge after randomization. Secondary outcomes included ICU and hospital LOS and 90-day all-cause mortality (Shehabi et al.).

The median days to antimicrobial discontinuation (Appendix B - 5) resulted in 11 and nine $(\mathrm{p}=0.58)$ in the control group compared to the procalcitonin group respectively (Shehabi et al., 2014). Intensive Care Unit mortality was found to be $8 \%$ in the control group versus $11 \%$ in the procalcitonin group $(\mathrm{p}=0.28)$. The 90 -day all-cause mortality 
from sepsis was $16 \%$ and $18 \%$ deaths in the control group compared to the procalcitonin group $(\mathrm{p}=0.60)$. As illustrated in Appendix C - 5, Shehabi et al. was able to conduct a quality study. A limitation to note is that the study used a low procalcitonin level of $0.1 \mathrm{ng} / \mathrm{ml}$ as the cutoff to discontinue antimicrobials. Most studies in the literature use a procalcitonin level of $0.5 \mathrm{ng} / \mathrm{ml}$ as the achievable level before discontinuing antimicrobials.

\section{Cross Study Analysis}

A cross study analysis of the studies (Appendix D - 1) showed three trials were conducted in a single center and only two studies included a multicentered approach. All five studies depicted a reduction of median days patients received antimicrobials (Annane et al.; Bishop et al.; Nobre et al.; Schroeder et al.; Shehabi et al.). Bishop et al., Nobre et al., and Schroeder et al. were able to show the reduction with clinical significance $(\mathrm{P}<$ $0.5)$. Four studies did not demonstrate a decrease or increase in mortality rates when using procalcitonin level to guide antimicrobial therapy in septic patients. Mortality rates between the intervention and control group were relatively similar, not demonstrating clinical significance.

Next, the summary and conclusions will be presented. 


\section{Summary and Conclusions}

Bacteria have evolved over time becoming more resistant to antimicrobials. Many factors have been identified as causative of bacterial resistance. Widespread and prolonged use of antimicrobials is a major contributing factor to bacterial resistance (Michael et al., 2014). Research reveals that countries that prescribe more antimicrobials observe higher rates of resistance (Lior \& Bjerrum, 2014).

Sepsis is a condition that affects approximately 200,000 people per year in the USA (Moore et al., 2016). Sepsis treatment requires the use of broad-spectrum antimicrobials until the causative agent of infection is identified; then, antimicrobial therapy is adjusted once culture and sensitivity test results are available. The length of time of antimicrobial therapy is then determined based upon the type and location of infection guided by principles of the Infectious Diseases Society of America (IDSA) (Leekha et al., 2011).

Antimicrobial therapy is continued to the end of the specified time recommended by the IDSA even if a patient is no longer displaying clinical symptoms of an active infection leading to prolonged antimicrobial exposure. Reducing the exposure time of antimicrobial therapy may reduce the incidence of bacterial resistance (Lior \& Bjerrum, 2014). There are many biomarkers being investigated to aid in determining the time of antimicrobial discontinuation.

Testing levels of procalcitonin remains at the forefront of promising options to guide antimicrobial therapy. A 2012 meta-analysis showed a reduction in the length of antimicrobial therapy in patients suffering from acute respiratory infections without causing an increase in mortality (Schuetz et al., 2012). The question remains if utilizing 
procalcitonin to guide antimicrobial therapy in patients suffering from sepsis reduces exposure a patient may experience.

The purpose of this systematic review was to assess if using procalcitonin levels to guide antimicrobial therapy has an impact on the number of days an adult septic patient is exposed to antimicrobial therapy. The research question asked if using procalcitonin levels to guide antimicrobial therapy has an impact on the number of days an adult septic patient is exposed to antimicrobial therapy. A literature review was first conducted by the author utilizing inclusion and exclusion criteria. The search strategy included the use of the following data bases: Google Scholar, Medline, Ovid, and PUBMED. The PRISMA flow diagram was used to demonstrate the search path and selection of studies. (Figure 1). Five articles met the inclusion criteria. The primary outcome investigated was the median duration of antimicrobial exposure experienced in a patient diagnosed with sepsis receiving care within an ICU. The secondary outcome measured was the mortality rate associated with antimicrobial therapy among patients treated traditionally versus use of procalcitonin levels.

Schroeder et al. (2008) was able to demonstrate the most clinically significant reduction in duration of antimicrobials $(\mathrm{P}<0.001)$. Although the investigators were able to show highly significant results, it is difficult to assume the same findings may be applied to a larger study or group because of the small sample size originally studied.

Nobre et al. (2008) demonstrated a reduction in antimicrobial therapy in the procalcitonin group with statistical significance and a $95 \%$ confidence interval $(\mathrm{P}=$ 0.003). Total antimicrobial exposure was also significantly witnessed in the procalcitonin group ( 655 vs $504,95 \% \mathrm{CI}, \mathrm{p}=0.0002)$. The authors observed no difference in 28-day 
mortality when the groups were compared. The mortality rate for both groups were equal. Nobre et al. successfully demonstrated antimicrobial exposure can be reduced utilizing procalcitonin levels without increasing 28 -day mortality when compared to empiric antimicrobial therapy.

The study performed by Annane et al. (2013) didn't demonstrate a clinically significant difference of duration of antimicrobials $(\mathrm{P}=0.52)$ between the procalcitonin and control group. The study only randomized a total of 58 patients making generalization difficult.

Bishop et al. (2014) demonstrated a clinically significant reduction in the length of antimicrobial therapy without a decrease in 30 -day mortality $(\mathrm{P}=0.0238)$. This study was strictly a single center observational study investigating the introduction of procalcitonin levels to a university hospital to aid in guiding antimicrobial therapy. Adherence rates to a specified procalcitonin algorithm were not recorded. Only 28 patients were categorized as having sepsis making it difficult to generalize results.

Shehabi et al., (2014) was not able to show a clinically significant duration of antimicrobial therapy following procalcitonin levels $(\mathrm{P}=0.58)$. Strengths of the study include a large randomized population of 394 patients and the investigators witnessed a high compliance rate with drawing procalcitonin levels and guiding their antimicrobials according to the level. A limitation to note is that the study used a low procalcitonin level of $0.1 \mathrm{ng} / \mathrm{ml}$ which may have contributed to the insignificant change of antimicrobial use among the groups; when most trials used a cutoff level of $0.5 \mathrm{ng} / \mathrm{ml}$. The 90 -day all-cause mortality was nearly identical between the procalcitonin group and control group (Shehabi et al.). 
The cross study analysis revealed that all studies included showed no change in mortality when using procalcitonin levels to guide therapy when compared to traditional administration. Three of the studies reported a decrease in antimicrobial therapy when discontinuing antimicrobials based upon procalcitonin levels with clinical significance (Bishop et al.; Nobre et al.; Schroeder et al.). Four studies showed a decrease in the duration of antimicrobial therapy without an increase in mortality (Annane et al.; Bishop et al.; Nobre et al.; and Shehabi et al.). One study did not include information regarding mortality rate (Schroeder et al., 2008).

There were several recognized limitations of the studies reviewed. Four of the studies contained a small sample size making generalization difficult (Annane et al.; Bishop et al.; Nobre et al.; Schroeder et al.). Three of the studies were conducted in a single center further making generalization difficult (Bishop et al.; Nobre et al.; Schroeder et al.). Specific algorithms were not easily defined in a significant proportion of the reviewed studies leading to questions regarding the cutoff procalcitonin levels utilized for discontinuation of antimicrobials. Physician compliance was only discussed in one of the five studies showing a significant amount of non-compliance. Providers may feel reluctant with discontinuing antimicrobials based upon an unproven theory.

Limitations exist in this systematic review. The total number of studies included in this systematic review was low at only five studies. The search for RCTs surrounding procalcitonin levels guiding antimicrobial therapy in the sepsis patient remains difficult. Analyzing a few RCTs leads to difficulty in generalizing the population. The RCTs included in this systematic review included varied demographics that often were not included in the studies. This also tended to make generalization difficult as there was not 
enough information presented to be confident in guiding clinical decisions based from these studies.

In conclusion, a clear determination of the use of procalcitonin levels in deciding to discontinue antimicrobial therapy remains unapparent. Further focused research is required to make a concise decision to discontinuing antimicrobials based on procalcitonin levels. The ideal procalcitonin level should be investigated and used throughout RCTs to better delineate the results of discontinuing antimicrobials. Randomized control trials should further describe the cause of sepsis to better understand how procalcitonin levels respond with specific infections. This may aid in understanding the specific cutoff level of procalcitonin needed to safely discontinue antimicrobials.

Next, the recommendations and implications for advanced nursing practice will be discussed. 


\section{Recommendations and Implications for Advanced Nursing Practice}

Advance Practice Registered Nurses (APRN) are increasingly utilized in the delivery of healthcare. It is widely accepted there will be physician shortages in the future. Advanced Practice Registered Nurses can supplement the shortage and have proven they can effectively manage patients by reducing length of stay, mortality, and costs associated with patient care (Yeong Woo, Lee, \& San Tam, 2017). It is increasingly fundamental for APRNs to stay current with knowledge, interpret research, and translate research into practice. Advance Practice Registered Nurses play an active role in the future of healthcare. They are fundamental in integrating and disseminating their knowledge through the use of professional organizations to change policies. Advance Practice Registered Nurses also engage in change at the forefront of healthcare delivery. Bacterial resistance to antimicrobials continues to be a problem in healthcare. It is hypothesized that prolonged exposure to antimicrobials contribute to bacterial resistance. Sepsis is a condition which integrates antimicrobials for treatment and often requires a prolonged course for treatment. There is no test in existence to indicate when discontinuation of antimicrobials is indicated. Discontinuation of antimicrobials based upon procalcitonin levels may reduce the number of days septic patients are exposed to antimicrobials.

It is the recommendation of this author that more RCTs should be conducted. The RCTs should include and present clear procalcitonin guidelines utilized for their trial. Randomized control trials should include a greater sample size to make generalization possible. It is further recommended that providers adhere to the treatment guidelines set 
by the investigators as evidence shows there is no change in mortality if antimicrobial therapy duration is reduced.

Procalcitonin may have a role in determining the appropriate time of discontinuing antimicrobial therapy in a septic patient. Evidence is mounting in the literature about procalcitonin use and utility, but many more trials should be conducted. Following procalcitonin levels alone may not be enough to guide the decision to discontinue antimicrobials. The usefulness of procalcitonin, along with other biomarkers, may be more reliable when used in conjunction with other biomarkers. Trending more than one biomarker together increases reliability and may reinforce the idea of discontinuing antimicrobial therapy. It is imperative that APRNs base their clinical decisions on the most evidence they obtain and not based upon one test result. At this time, it is not recommended that procalcitonin levels used alone is diagnostic of infection.

Guidelines and policies are often created by multidisciplinary teams. Nurse Practitioners (NPs) are increasingly involved in multidisciplinary teams and assists or leads policy development. Policy development often includes developing guidelines to provide a standard of care. Nurse Practitioners may utilize this review to help develop guidelines for procalcitonin's use. Policies are established in conjunction with guidelines and serve as a guide to aid providers in making decisions that impact the care of their patients. Nurse practitioners can further implement the guidelines developed through providing education and training to personnel impacted by the guidelines.

Advance Practice Registered Nurses may utilize this review in providing education and training to peers regarding the use of procalcitonin in the septic patient. This review provides necessary information to adequately decide on procalcitonin's 
utility in practice. Collaboration with other providers are integral to the NP role. Nurse Practitioners are situated in a position to be an expert on the topic of procalcitonin's use and may provide informal or formal training to their colleagues. 


\section{References}

Annane, D., Maxime, V., Faller, J. P., Mezher, C., Clec'h, C., Martel, P., ... Nardi, O. (2013). Procalcitonin levels to guide antibiotic therapy in adults with nonmicrobiologically proven apparent severe sepsis: A randomized controlled trial. BMJ Open, 3, 1-7. http://dx.doi.org/10.1136/bmjopen-2012-002186

Biron, B.M., Ayala, A., \& Lomas-Neira, J.L. (2015). Biomarkers for sepsis: What is and what might be. Libertas Academica, 10(4), 7-17. http://dx.doi.org/10.4137/BMI.S29519

Bishop, B. M., Bon, J. J., Trienski, T. L., Pasquale, T. R., Martin, B. R., \& File Jr, T. M. (2014). Effect of introducing procalcitonin on antimicrobial therapy duration in patients with sepsis and/or pneumonia in the intensive care unit. Annals of Pharmacotherapy, 48(5), 577-583. http://dx.doi.org/10.1177/1060028014520957

Chausse, J. M., Malekele, L., \& Paruk, F. (2018). Improved understanding of the pathophysiology of sepsis: Setting the scene for potential novel adjunctive therapies. South African Journal of Critical Care, 34(1), 4-8. http://dx.doi.org/10.7196/SAJCC.201.v34i1.361

Cote, G. J., Grubbs, E. G., \& Hofmann, M. (2015). Thyroid c-cell biology and oncogenic transformation. In Recent Results in Cancer Research, pp. 1-39. http://dx.doi.org/10.1007/978-3-319-22542-5_1

Critical Appraisal Skills Programme. (2019). Retrieved from https://casp-uk.net

Daley, M. D. (2016). Meta-analyses: Merits, limitations, and application of the PRISMA statement. American Medical Writers Association Journal, 31(1), 12-19. Retrieved from https://www.amwa.org 
Davies, J. (2015). Procalcitonin. Journal of Clinical Pathology, 68, 675-679. http://dx.doi.org/10.1136/jclinpath-2014-202807

Esmon, C.T. (2005). The interactions between inflammation and coagulation. British Journal of Haematology, 131, 417-430. http://dx.doi.org/10.1111/j.13652141.2005.05753.x

Epstein, L., Dantes, R., Magill, S., \& Fiore, A. (2016). Varying estimates of sepsis mortality using death certificates and administrative codes - United States, 19992014. Morbidity and Mortality Weekly Report, 65(13), 342-342. http://dx.doi.org/http://dx.doi.org/10.15585/mmwr.mm6513a2

Ferreira, F.L., Bota, D.P., Bross, A., Melot, C., \& Vincent, J. (2001). Serial evaluation of the sofa score to predict outcome in critically ill patients. Journal of the American Medical Association, 286(14), 1754-1758.

http://dx.doi.org/10.1001/jama.286.14.1754

Genga, K.R., \& Russell, J. A. (2017). Update of sepsis in the intensive care unit. Journal of Innate Immunity, (9), 441-455. Http://dx.doi.org/10.1159/000477419

Leekha, S., Terrell, C. L., \& Edson, R. S. (2011). General principles of antimicrobial therapy. Mayo Clinic Proceedings, 86(2), 156-167. http://dx.doi.org/https://doi.org/10.4065/mcp.2010.0639

Levy, M. M., Evans, L. E., \& Rhodes, A. (2018). The surviving sepsis campaign bundle: 2018 update. Intensive Care Medicine, 44(6), 925-928. http://dx.doi.org/10.1097/CCM.0000000000003119

Liberati, A., Altman, D. G., Tetzlaff, J., Mulrow, C., Gotzsche, P. C., Ioannidis, J. P., ... Moher, D. (2009). The prisma statement for reporting systematic reviews and 
meta-analyses of studies that evaluate health care interventions: explanation and elaboration. Plos Medicine.

http://dx.doi.org/https://doi.org/10.1371/journal.pmed.1000100

Lior, C., \& Bjerrum, L. (2014). Antimicrobial resistance: Risk associated with antibiotic overuse and initiatives to reduce the problem. Therapeutic Advances in Drug Safety, 229-241. http://dx.doi.org/10.1177/2042098614554919

Marik, P. E., \& Taeb, A. M. (2017). SIRS, qSOFA and new sepsis definition [Editorial]. Journal of Thoracic Disease, 9(4), 943-945. http://dx.doi.org/10.21037/jtd.2017.03.125

Michael, C. A., Dominey-Howes, D., \& Labbate, M. (2014). The antimicrobial resistance crisis: causes, consequences, and management. Frontiers in Public Health, 2(2), 1-8. http://dx.doi.org/10.3389/fpubh.2014.00145

Moher, D., Liberati, A., Tetzlaff, J., \& Altman, D. G. (2009). Preferred reporting items for systematic reviews and meta-analyses: The PRISMA statement. Annals of Internal Medicine, 151(4), 264-269. Retrieved from www.annals.org Moore, J. X., Donnelly, J. P., Griffin, R., Howard, G., Safford, M. M., \& Wang, H. E. (2016). Defining sepsis clusters in the United States. Critical Care Medicine, 44(7), 1380-1387. http://dx.doi.org/doi:10.1097/CCM.0000000000001665

Munita, J. M., \& Arias, C. A. (2016). Mechanisms of antibiotic resistance. Microbiology Spectrum, 4(2), 1-37. http://dx.doi.org/10.1128/microbiolspec.VMBF-0016-2015

Nair, R., Bhandary, N. M., \& D'Souza, A. D. (2016). Initial sequential organ failure assessment score versus simplified acute physiology score to analyze multiple organ dysfunction in infectious diseases in intensive care unit. Indian Journal of 
Critical Care Medicine, 20(4), 210-215. http://dx.doi.org/10.4103/09725229.180041

Nobre, V., Harbarth, S., Graf, J., Rohner, P., \& Pugin, J. (2008). Use of procalcitonin to shorten antibiotic treatment duration in septic patients: a randomized trial. American Journal of Respiratory and Critical Care Medicine, 177(), 498-505. http://dx.doi.org/10.1164/rccm.200708-123OC

Paoli, C. J., Reynolds, M. A., Sinha, M., Gitlin, M., \& Crouser, E. (2018). Epidemiology and costs of sepsis in the United States - an analysis based on timing of diagnosis and severity level. Critical Care Medicine, 46(12), 1889-1897. http://dx.doi.org/10.1097/CCM.0000000000003342

Polat, G., Ugan, R. A., Cadirci, E., \& Halici, Z. (2017). Sepsis and septic shock: Current treatment strategies and new approaches. The Eurasian Journal of Medicine, 5358. http://dx.doi.org/10.5152/eurasianjmed.2017.17062

Raith, E. P., Udy, A. A., \& Bailey, M. (2017). Prognostic accuracy of the sofa score, sirs criteria, and qsofa score for in hospital mortality amond adults with suspected infection admitted to the intensive care unit. Journal of the American Medical Association, 317(3), 290-300. http://dx.doi.org/10.1001/jama.2016.20328

Roca, I., Akova, M., Baquero, F., Carlet, J., Cavaleri, M., Coenen, S., ... Villa, J. (2015). The global threat of antimicrobial resistance: science for intervention. New Microbes and New Infections, 6, 22-29. http://dx.doi.org/10.1016/j.nmni.2015.02.007

Schroeder, S., Hachreiter, M., Koehler, T., Schweiger, A. M., Bein, B., Keck, F. S., \& Spiegel, T., (2008). Procalcitonin (PCT) - guided algorithm reduces length of 
antibiotic treatment in surgical intensive care patients with severe sepsis: results of a prospective randomized study. Langenbecks Archive of Surgery, 394(), 221226. http://dx.doi.org/10.1007/s00423-008-0432-1

Schuetz, P., Birkhahn, R., Sherwin, R., Jones, A. E., Singer, A., Kline, J. A., ... Shapiro, N. I. (2017). Serial procalcitonin predicts mortality in severe sepsis patients: Results from the multicenter procalcitonin monitoring sepsis (MOSES) study. Critical Care Medicine, 45(5), 7891-789. http://dx.doi.org/10.1097/CCM.0000000000002321

Schuetz, P., Briel, M., Christ-Crain, M., Stolz, D., Bouadma, L., Wolff, M., ... Mueler, B. (2012). Procalcitonin to guide initiation and duration of antibiotic treatment in acute respiratory infections: an individual patient data meta-analysis. Clinical Infectious Diseases, 55 (5), 651-662. http://dx.doi.org/10.1093/cid/cis464

Schuetz, P., Briel, M., \& Mueller, B. (2013). Clinical outcomes associated with procalcitonin algorithms to guide antibiotic therapy in respiratory tract infections. Journal of the American Medical Association, 309(7), 717-718. Retrieved from https://www.researchgate.net/profile/Beat_Mueller3/publication/235669686_Clini cal_Outcomes_Associated_With_Procalcitonin_Algorithms_to_Guide_Antibiotic _Therapy_in_Respiratory_Tract_Infections/links/0c96052dadaf36e4a6000000/Cli nical-Outcomes-Associated-With-Procalcitonin-Algorithms-to-Guide-AntibioticTherapy-in-Respiratory-Tract-Infections.pdf

Shehabi, Y., Sterba, M., Garrett, P. M., Rachakonda, K. S., Stephens, D., Harrigan, P., ... Fraser, J. F. (2014). Procalcitonin algorithm in critically ill adults with undifferentiated infection or suspected sepsis: A randomized controlled trial. 
American Journal of Respiratory and Critical Care Medicine, 190(10), 1102-

1110. http://dx.doi.org/10.1164/rccm.201408-1483OC

Silva, B., Atallah, A., \& Salomao, R. (2013). De-escalation of antimicrobial treatment for adults with sepsis, severe sepsis or septic shock. Cochrane Database of Systematic Reviews, (3), 1-32. http://dx.doi.org/10.1002/14651858.CD007934.pub3

Singer, M., Deutschman, C. S., Seymour, C. W., Shankar-Hari, M., Anane, D., Bauer, M., ,.. Angus, D. C. (2016). The third international consensus definitions for sepsis and septic shock. The Journal of the American Medical Association, 315(8), 801-810. http://dx.doi.org/10.1001/jama.2016.0287

Society of Critical Care Medicine and European Society of Intensive Care Medicine. (2016). Surviving sepsis campaign: international guidelines for management of sepsis and septic shock: 2016 (Press Release). Retrieved from http://survivingsepsis.org

Stimbu, K., \& Tavel, J, A. (2010). What are biomarkers? Current Opinion HIV and AIDS, 5(6), 463-466. http://dx.doi.org/10.1097/COH.0b013e32833ed177

Surviving Sepsis Campaign website. (n.d.). https://www.survivingsepsis.org

Thong, B. Y., \& Seng, T. T. (2010). Epidemiology and risk factors for drug allergy. British Pharmacological Society, 71(5). http://dx.doi.org/10.1111/j.13652125.2010.03774.x

Vincent, J. (2016). The clinical challenge of sepsis identification an monitoring. Plos Medicine, 13(5), 1-10. http://dx.doi.org/10.1371/jounal.pmed.1002022 
Yeong Woo, B.F., Lee, J., \& San Tam, W. W. (2017). The impact of the advanced practice nursing role on quality of care, clinical outcomes, patient satisfaction, and cost in the emergency and critical care settings: a systematic review. Human Resources for Health, 15(63). http://dx.doi.org/10.1186/s12960-017-0237-9 


\section{Appendix A-1}

\section{Data Collection Tool 1}

Nobre, V., Harbarth, S., Graf, J., Rohner, P., \& Pugin, J. (2008). Use of procalcitonin to shorten antibiotic treatment duration in septic patients: a randomized trial. American Journal of Respiratory and Critical Care Medicine, 177, 498-505: http://doi.org/10.1164/rccm.200708-12380C

\begin{tabular}{|c|c|c|}
\hline Purpose & Study Design/Setting/Sample & Method \\
\hline $\begin{array}{l}\text { Test whether an algorithm } \\
\text { based on daily evolution of } \\
\text { plasma procalcitonin levels } \\
\text { would help clinicians } \\
\text { shorten the duration of } \\
\text { antimicrobial therapy in } \\
\text { critically ill patients with } \\
\text { suspected or documented } \\
\text { severe sepsis and septic } \\
\text { shock. }\end{array}$ & $\begin{array}{l}\text { Design: randomized, } \\
\text { controlled, open } \\
\text { interventional trial } \\
\text { Setting: The University } \\
\text { Hospitals of Geneva, } \\
\text { Switzerland } \\
\text { - } \quad 1200 \text { bed tertiary care } \\
\quad \text { hospital } \\
\text { Sample: all patients with } \\
\text { suspected severe sepsis or } \\
\text { septic shock admitted to the } \\
\text { ICU from February } 2006 \text { to } \\
\text { April } 2007 \text { were assessed for } \\
\text { eligibility } \\
\text { - } 32 \text { bed mixed } \\
\quad \text { medical/surgical ICU }\end{array}$ & $\begin{array}{l}\text { Randomization: performed using a computer-based random number } \\
\text { generation. } \\
\text { - Allocation made by using opaque, sealed, numbered envelopes } \\
\text { - All patients included had a circulating procalcitonin level } \\
\text { measured at baseline and daily until the } 7^{\text {th }} \text { day or until } \\
\text { antimicrobials were stopped if before the } 7^{\text {th }} \text { day. } \\
\text { Inclusion: all patients with suspected severe sepsis or septic shock } \\
\text { admitted to ICU. } \\
\text { - Included patients developing suspected severe sepsis or septic } \\
\text { shock while in the ICU } \\
\text { Exclusion: } \\
\text { - Microbiologically documented infections caused by the } \\
\text { following } \\
\text { O Pseudomonas aeruginosa } \\
\text { O Acinetobacter baumanni } \\
\text { O Listeria spp. } \\
\circ \text { Legionella pneumophila } \\
\text { O Pneumocystis jiroveci }\end{array}$ \\
\hline
\end{tabular}




\begin{tabular}{|c|c|c|}
\hline & $\begin{array}{l}\text { - } 282 \text { patients assessed for } \\
\text { eligibility } \\
\text { - } 203 \text { excluded } \\
\text { - } 79 \text { patients randomized } \\
\text { - } 39 \text { assigned to } \\
\text { intervention group } \\
\quad \text { o } 31 \text { completed trial } \\
\text { - } 40 \text { assigned to control } \\
\text { group } \\
\text { o } 37 \text { completed trial } \\
\text { - Total patients completing } \\
\text { trial } n-68\end{array}$ & $\begin{array}{l}\text { ○ Mycobacterium tuberculosis } \\
\text { - Severe infections due to viruses or parasites } \\
\text { - Infectious conditions requiring prolong antimicrobial therapy } \\
\text { - Antimicrobial therapy begun } 48 \text { hours or more before enrollment } \\
\text { - Chronic localized infections } \\
\text { - Chronic osteomyelitis } \\
\text { - Immunocompromised patients: } \\
\circ \text { CD4 count }<200 \text { cells } / \mathrm{mm} 3 \\
\circ \text { Neutropenic }<500 \text { neutrophils } / \mathrm{mm} 3 \\
\circ \quad \text { Patients on immunosuppressive therapy after solid organ } \\
\quad \text { transplantation } \\
\text { - Withholding of life support }\end{array}$ \\
\hline
\end{tabular}




\section{Appendix A-2}

\section{Data Collection Tool 1}

Schroeder, S., Hochreiter, M., Koehler, T., Schweiger, A.M., Bein, B., Keck, F. S., \& von Spiegel, T. (2008). Procalcitonin (PCT)guided algorithm reduces length of antibiotic treatment in surgical intensive care patients with severe sepsis: results of a prospective randomized study. Lagenbecks Archives of Surgery, 394, 221-226. http://dx.doi.org/10.1007/s00423-008-0432-1

\begin{tabular}{|c|c|c|}
\hline Purpose & Study Design/Setting/Sample & Method \\
\hline $\begin{array}{l}\text { Investigate the clinical } \\
\text { usefulness of procalcitonin levels } \\
\text { for guiding antimicrobial } \\
\text { treatment in surgical intensive } \\
\text { care patients with severe sepsis }\end{array}$ & $\begin{array}{l}\text { Design: prospective randomized study } \\
\text { Setting: Intensive care unit of the } \\
\text { Department of Anesthesiology and } \\
\text { Intensive Care Medicine of the } \\
\text { Westkustenklinikum Heide } \\
\text { Sample: patients from October } 2006 \\
\text { and April } 2007 \text { were eligible for the } \\
\text { study } \\
\text { - } 125 \text { patients screened } \\
\text { - } 27 \text { patients eligible for study } \\
\text { Intervention group: } n=14 \\
\text { - Mean age }=69 \\
\text { - Male gender }=8 \\
\text { - Diagnoses } \\
\text { O Peritonitis: } 10 \\
\circ \quad \text { Pneumonia: } 4 \\
\text { Control group: } n=13\end{array}$ & $\begin{array}{l}\text { Patients were screened from October } 2006 \text { to April } \\
2007 \text { and randomly assigned to either the intervention } \\
\text { or control group } \\
\text { Inclusion criteria: patients met the criteria by fulfilling } \\
\text { the definition of severe sepsis after abdominal surgery } \\
\text { Exclusion Criteria: patients excluded if did not meet } \\
\text { the respective inclusion criteria, refused informed } \\
\text { consent, or already had received antibiotic treatment } \\
\text { prior to admission to the ICU }\end{array}$ \\
\hline
\end{tabular}




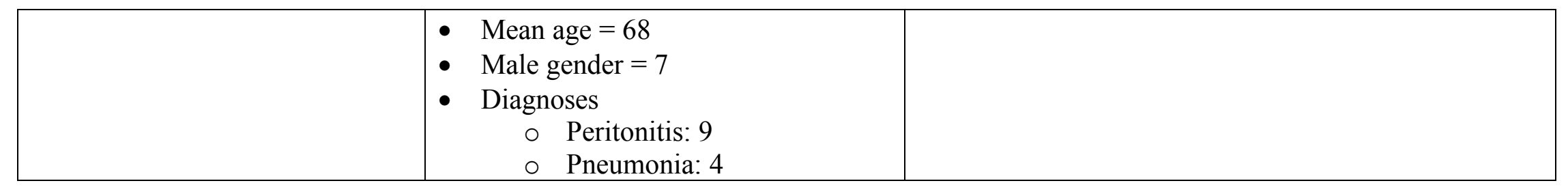




\section{Appendix A-3}

\section{Data Collection Tool 1}

Annane, D., Maxime, V., Faller, J. P., Mezher, C., Flech, C., Martel, P., ... Nardi, O. (2013). Procalcitonin levels to guide antibiotic therapy in adults with non-microbiologically proven appareant severe sepsis: A randomized controlled trial. BMJ Open, 3, 1-7. http://dx.doi.org/10.1136/bmjopen-2012-002186

\begin{tabular}{|c|c|c|}
\hline Purpose & Study Design/Setting/Sample & Method \\
\hline $\begin{array}{l}\text { To investigate whether a } \\
\text { procalcitonin-based algorithm } \\
\text { influenced antibiotic use in } \\
\text { patients with non- } \\
\text { microbiologically proven } \\
\text { apparent sepsis } \\
\text { Primary outcome: the proportion } \\
\text { of patients on antimicrobials on } \\
\text { day } 5 \text { post randomization } \\
\text { Secondary outcomes: } \\
\text { - Death at day } 5 \text {, ICU } \\
\text { discharge and at hospital } \\
\text { discharge } \\
\text { Proportion of patients started } \\
\text { on antimicrobials post } \\
\text { randomization }\end{array}$ & $\begin{array}{l}\text { Design: multicenter, randomized } \\
\text { controlled, single-blind trial } \\
\text { Setting: } 2 \text { parallel groups at } 8 \\
\text { centers in France in the intensive } \\
\text { care unit } \\
\text { Sample: taken from December } \\
2006 \text { to December } 2009 \\
\text { - Only } 58 \text { patients met eligibility } \\
\quad \text { criteria } \\
\text { Control Arm: } n=28 \\
\text { - Mean age } 54 \\
\text { - Female gender } 32.1 \% \\
\text { Procalcitonin based algorithm: } \\
\text { n=30 } \\
\text { - Mean age } 59\end{array}$ & $\begin{array}{l}\text { Patients were eligible if admitted to ICU for }<48 \text { hours } \\
\text { and met the following: } \\
\text { - Clinical signs of systemic inflammatory response } \\
\text { - } \text { syndrome } \\
\text { - } \text { Dysfunction of at least } 1 \text { organ } \\
\text { - Negative microbiological cultures } \\
\text { Exclusion criteria were: } \\
\text { - Pregnancy } \\
\text { - Burns }>15 \% \text { body surface area (BSA) } \\
\text { - Trauma } \\
\text { - Outpatient or inpatient cardiac arrest } \\
\text { - Post-orthopedic surgery } \\
\text { - Drug related neutropenia } \\
\text { - Withdrawal of life supportive therapies or decision to } \\
\text { withhold them }\end{array}$ \\
\hline
\end{tabular}


- Duration of antimicrobial exposure

- Sequential Organ Failure Assessment (SOFA) Score at day 3 and day 5

- Proportion of patients with infection acquired between randomization and day 3 , day 5 , and ICU discharge

- Length of Stay (LOS) in ICU and total hospital stay
- Female gender $20 \%$

Total randomized patients after accounting for loss consents

- $n=53$
- Indisputable infection or antimicrobial exposure $>48$ hours during the time before ICU admission

Randomization:

- 1:1 ratio according to a computer-generated list

- Centralized through a secured website and completed by an independent statistician

Blinding:

- Control arm: patients, physicians, nurses, investigators, study coordinators, the statisticians remained blinded to procalcitonin levels throughout the study 


\section{Appendix A-4}

\section{Data Collection Tool 1}

Bishop, B.M., Bon, J. J., Trienski, T. L., Pasquale, T.R., Martin, B.R., \& File Jr, T.M. (2014). Effect of introducing procalcitonin on antimicrobial therapy duration in patients with sepsis and/or pneumonia in the intensive care unit. Annals of Pharmocotherapy, 48(5), 577-583. http://dx.doi.org/10.1177/1060028014520957

\begin{tabular}{|c|c|c|}
\hline Purpose & tudy Design/Setting/Sample & lethod \\
\hline $\begin{array}{l}\text { Evaluate the impact of } \\
\text { introducing rapid turnaround } \\
\text { procalcitonin testing at a } \\
\text { large, academic teaching } \\
\text { hospital on antimicrobial use } \\
\text { in critically ill patients with } \\
\text { pneumonia and/or sepsis } \\
\text { Primary outcome: initial } \\
\text { duration of antimicrobial } \\
\text { therapy, defined as number of } \\
\text { days from start to the } \\
\text { intentional discontinuation of } \\
\text { antimicrobial therapy for }>24 \\
\text { hours } \\
\text { Secondary outcomes: } \\
\text { - Length of stay (LOS) in } \\
\quad \text { hospital }\end{array}$ & $\begin{array}{l}\text { Design: prospective, observational, case- } \\
\text { control study } \\
\text { Setting: } 109 \text { bed tertiary medical/surgical } \\
\text { intensive care unit } \\
\text { Sample: patients in the procalcitonin group } \\
\text { were enrolled from September } 2012 \text { to } \\
\text { January } 2013 \\
\text { Procalcitonin group: } \mathrm{n}=50 \\
\text { - Mean age } 64 \\
\text { - Male gender } 64 \% \\
\text { - Diagnosis } \\
\quad \text { Pneumonia: } 35 \\
\quad \text { Sepsis: } 11 \\
\text { O Both: } 4 \\
\text { Control group: } n=50\end{array}$ & $\begin{array}{l}\text { Eligibility: diagnosis determination was based on } \\
\text { diagnosis-related group codes assigned to patients } \\
\text { Included patients who were } 18 \text { years or older and met } \\
\text { the following criteria } \\
\text { - Baseline procalcitonin level measured within } 12 \\
\text { hours of admission to the ICU or was in the ICU } \\
\text { with newly suspected infectious process of } \\
\text { pneumonia and/or sepsis } \\
\text { - Received } 1 \text { follow-up procalcitonin measurement } \\
\text { at least } 48 \text { hours after initial level } \\
\text { Exclusion criteria: } \\
\text { - Neutropenic patients ( }<500 \text { neutrophils } / \text { mL) } \\
\text { Immunosuppressed patients (i.e., chemotherapy, } \\
\text { radiation therapy, or immunosuppressive } \\
\text { therapy), or chronic steroid use (defined as }>3 \\
\text { months of prednisone } 7.5 \mathrm{mg} / \mathrm{d} \text { or of a prednisone } \\
\text { equivalent) }\end{array}$ \\
\hline
\end{tabular}


- LOS in the ICU

- Readmission to the ICU during the index admission

- 300-day readmissions for any reason

- 30-day readmission to hospital for infections causes

- 30-day mortality

- Relapse of infection: defined as reinitiation of antimicrobials for the initial infection after antimicrobials were stopped for $>24$ hours
- Mean age 61

- Male gender $64 \%$

- Diagnosis

○ Pneumonia: 39

- Sepsis: 8

o Both: 3
- Patients with $>24$ hours of antimicrobial therapy prior to initial procalcitonin measurement

- Patients diagnosed with infections requiring longterm antimicrobial therapy (i.e., endocarditis, osteomyelitis, anterior mediastinitis post-cardiac surgery, hepatic or cerebral abscess, chronic prostatitis, or infection with mycobacterium tuberculosis, pneumocystis jirovecii, or toxoplasma gondii)

- Patients who had "Do not Rescusitate" orders

- Patients who had a poor chance of survival based upon Acute Physiology and Chronic Health Evaluation II (APACHE II) score $>25$

Procalcitonin algorithm was included in the procalcitonin level order

Control: The procalcitonin group was matched to historical controls admitted to same institution from January 2011 to 2011 on primary diagnosis, gender, age, APACHE II criteria and score 


\section{Appendix A-5}

\section{Data Collection Tool 1}

Shehabi, Y., Sterba, M., Garrett, P. M., Rachakonda, K. S., Stephens, D., Harrigan, P., ... Fraser, J. F. (2014). Procalcitonin algorithm in critically ill adults with undifferentiated infection or suspected sepsis: a randomized controlled trial. American Journal of Respiratory and Critical Care Medicine, 190(10), 1102-1110. http://dx.doi.org/10.1164/rccm.201408-1483OC

\begin{tabular}{|c|c|c|}
\hline Purpose & Study Design/Setting/Sample & Method \\
\hline $\begin{array}{l}\text { To investigate the effect of a } \\
\text { low procalcitonin cut-off on } \\
\text { antimicrobial prescriptions } \\
\text { Primary outcome: the } \\
\text { cumulative number of } \\
\text { antimicrobial treatment days } \\
\text { at day } 28\end{array}$ & $\begin{array}{l}\text { Design: prospective, single- } \\
\text { blind, randomized, } \\
\text { controlled, investigator- } \\
\text { initiated trial } \\
\text { Setting: } 11 \text { Australian } \\
\text { intensive care units } \\
\text { - Conducted in Australia } \\
\quad \text { between March } 2011 \text { and } \\
\quad \text { December } 2012 \\
\text { Sample: } 1567 \text { patients } \\
\text { screened } \\
\text { - } 1167 \text { excluded } \\
\text { - } 400 \text { total patients } \\
\text { randomized } \\
6 \text { withdrawn } \\
\text { Intervention group: } \mathrm{n}=196\end{array}$ & $\begin{array}{l}\text { Randomization: patients were variable block randomized 1:1 } \\
\text { through a secured central study website. } \\
\text { - Randomized to either a procalcitonin group or clinician-guided } \\
\text { group } \\
\text { - Stratified according to the presence of septic shock (defined by } \\
\text { receipt of inotropes and/or any vasopressors within the previous } \\
24 \text { hours } \\
\text { Eligibility criteria: } 18 \text { years and older } \\
\text { - Admitted to the ICU within the precious } 72 \text { hours receiving } \\
\text { parenteral and/or enteral antimicrobials for suspected bacterial } \\
\text { infection } \\
\text { - With two or more systemic inflammatory response syndrome } \\
\text { criteria } \\
\text { Expected to remain in the ICU for longer than } 24 \text { hours } \\
\text { Exclusion criteria: } \\
\text { - Patients receiving antimicrobials for surgical prophylaxis }\end{array}$ \\
\hline
\end{tabular}




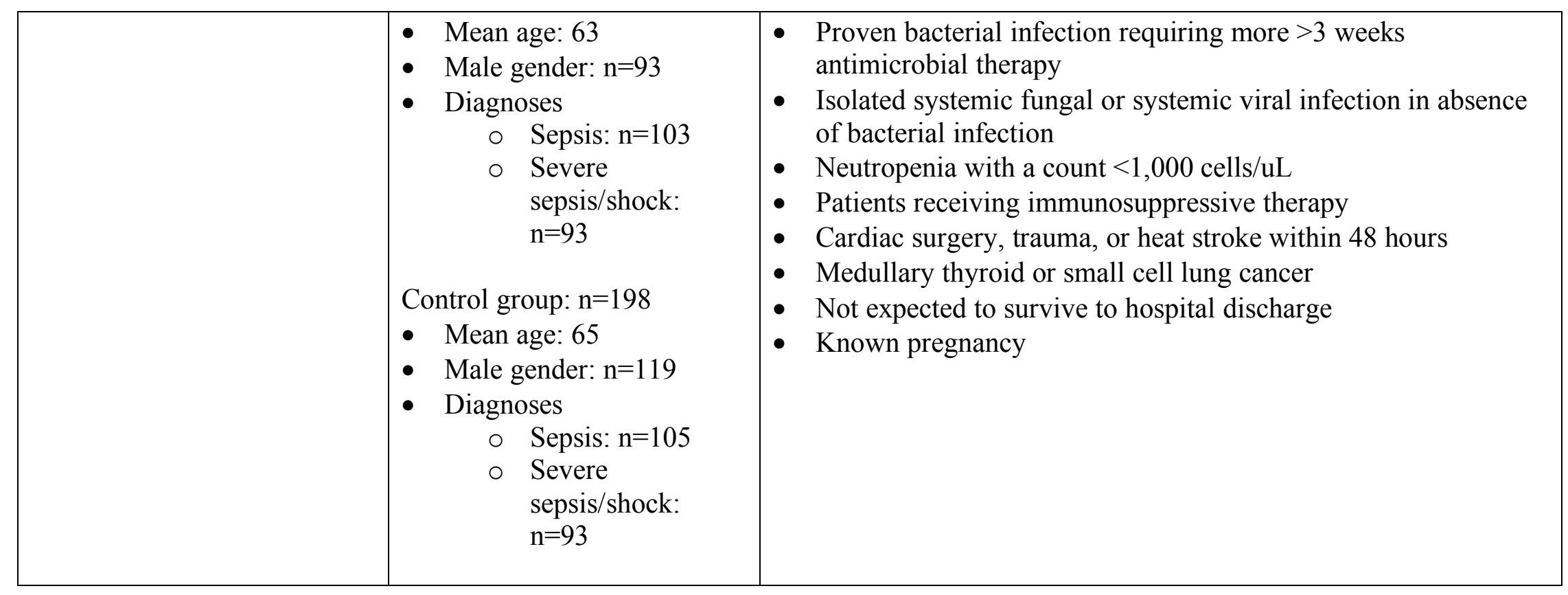




\section{Appendix B-1}

\section{Data Collection Tool 2}

Nobre, V., Harbarth, S., Graf, J., Rohner, P., \& Pugin, J. (2008). Use of procalcitonin to shorten antibiotic treatment duration in septic patients: a randomized trial. American Journal of Respiratory and Critical Care Medicine, 177, 498-505: http://doi.org/10.1164/rccm.200708-12380C

\begin{tabular}{|c|c|c|c|c|c|}
\hline \multicolumn{2}{|c|}{ Treatment Methods } & \multicolumn{2}{|c|}{$\begin{array}{c}\text { Total Days Receiving } \\
\text { Antimicrobials }\end{array}$} & \multirow{2}{*}{\multicolumn{2}{|c|}{ Results }} \\
\hline Intervention Group & Control Group & $\begin{array}{l}\text { Intervention } \\
\text { Group }\end{array}$ & Control Group & & \\
\hline \multirow{3}{*}{\multicolumn{2}{|c|}{$\begin{array}{l}\text { Procalcitonin Levels } \\
\text { - Measure at baseline and daily until the } \\
7^{\text {th }} \text { day of follow up } \\
\text { - Then measured every } 5 \text { days even if } \\
\text { the patient was transferred out of the } \\
\text { ICU }\end{array}$}} & \multirow{8}{*}{$\begin{array}{l}\text { Duration of } \\
\text { antimicrobial } \\
\text { therapy, } \\
\text { median day } \\
\text { and (range) } \\
\text { - } \quad 6(3-34) \\
\text { - } \quad P=0.003\end{array}$} & \multirow{8}{*}{$\begin{array}{l}\text { Duration of } \\
\text { antimicrobial } \\
\text { therapy, } \\
\text { median day } \\
\text { and (range) } \\
\text { - } \quad 10(3-33) \\
\text { - } \quad P=0.003\end{array}$} & \multicolumn{2}{|c|}{ Clinical Demographics: } \\
\hline & & & & Control group & Intervention group \\
\hline & & & & $65 \%$ & $71 \%$ \\
\hline \multirow{5}{*}{\multicolumn{2}{|c|}{$\begin{array}{l}\text { Antimicrobial Treatment: } \\
\text { - All patients received initial } \\
\text { antimicrobial therapy based on } \\
\text { organization guidelines, susceptibility, } \\
\text { and treating physician who was blinded } \\
\text { to the study } \\
\text { Broad spectrum antimicrobials were } \\
\text { given to patients with suspected severe } \\
\text { sepsis or septic shock according to the }\end{array}$}} & & & \multicolumn{2}{|c|}{$\mathrm{P}=0.35$} \\
\hline & & & & \multicolumn{2}{|c|}{ Sepsis of Pulmonary Origin } \\
\hline & & & & Control group & Intervention group \\
\hline & & & & $67 \%$ & $64 \%$ \\
\hline & & & & \multicolumn{2}{|c|}{$\mathrm{P}=0.93$} \\
\hline
\end{tabular}


suspected source of infection and microbiological cultures when available, then narrowed according to susceptibility testing

Procalcitonin Levels

- Measured the same as above but stopped when antimicrobial therapy was discontinued according to procalcitonin levels

- Procalcitonin levels provided

\begin{tabular}{|c|c|}
\hline \multicolumn{2}{|c|}{ Septic Shock } \\
\hline Control group & Intervention group \\
\hline $42 \%$ & $43.6 \%$ \\
\hline \multicolumn{2}{|c|}{$\mathrm{P}=0.89$} \\
\hline
\end{tabular}

\begin{tabular}{|c|c|}
\hline \multicolumn{2}{|c|}{28 Day Mortality } \\
\hline Control group & Intervention group \\
\hline $20 \% \quad 20.5 \%$ \\
\hline \multicolumn{2}{|c|}{$\mathrm{P}=0.82$} \\
\hline
\end{tabular}

Procalcitonin

Levels

- Procalcitonin levels kept in the laboratory and not communicated to treating physicians

Study Investigators:

\begin{tabular}{|c|c|}
\hline \multicolumn{2}{|c|}{ Median PCT levels on admission } \\
\hline Control group & Intervention group \\
\hline $5.9 \mu \mathrm{g} / \mathrm{L}$ & $8.4 \mu \mathrm{g} / \mathrm{L}$ \\
\hline \multicolumn{2}{|c|}{$\mathrm{P}=0.75$} \\
\hline
\end{tabular}




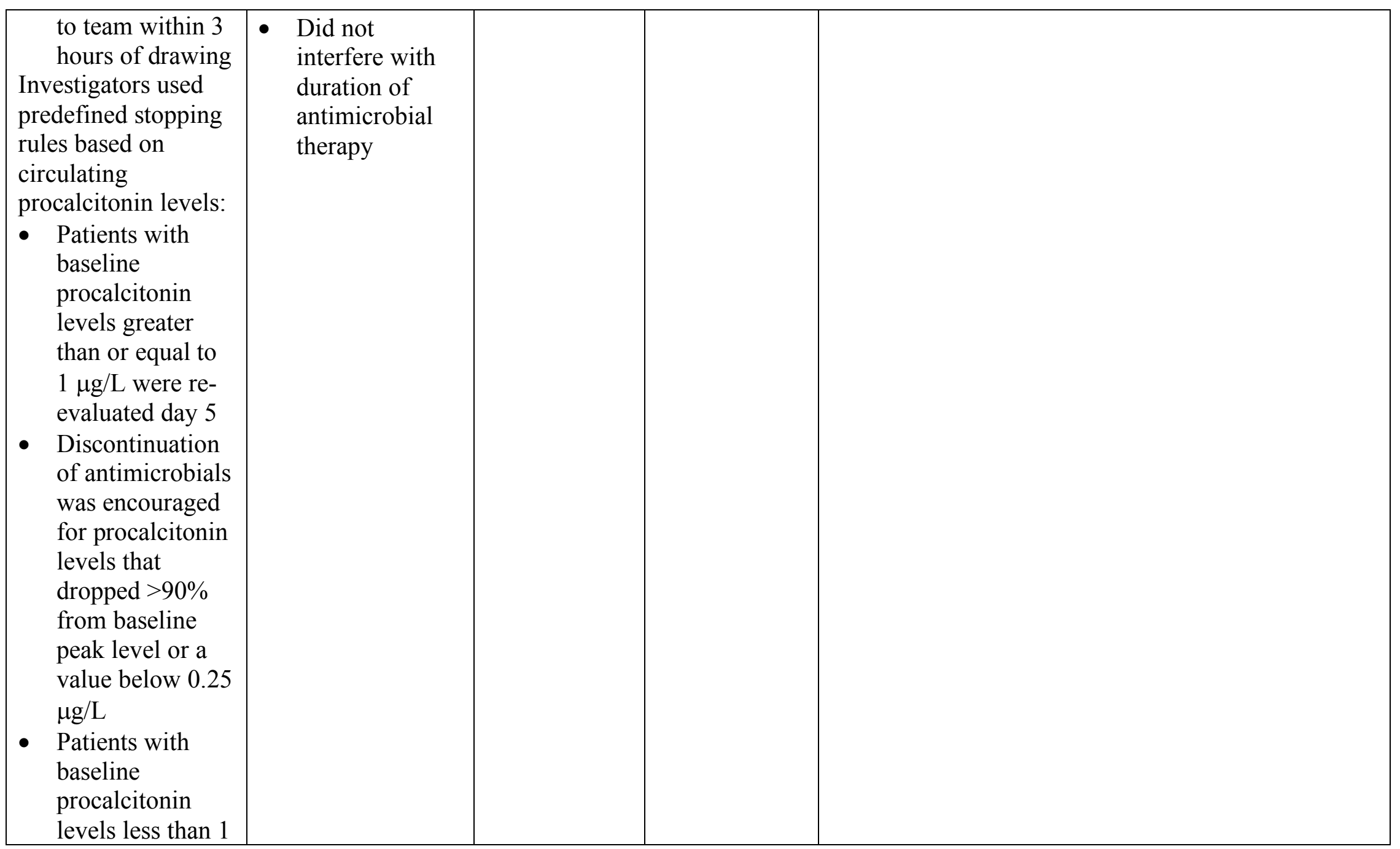




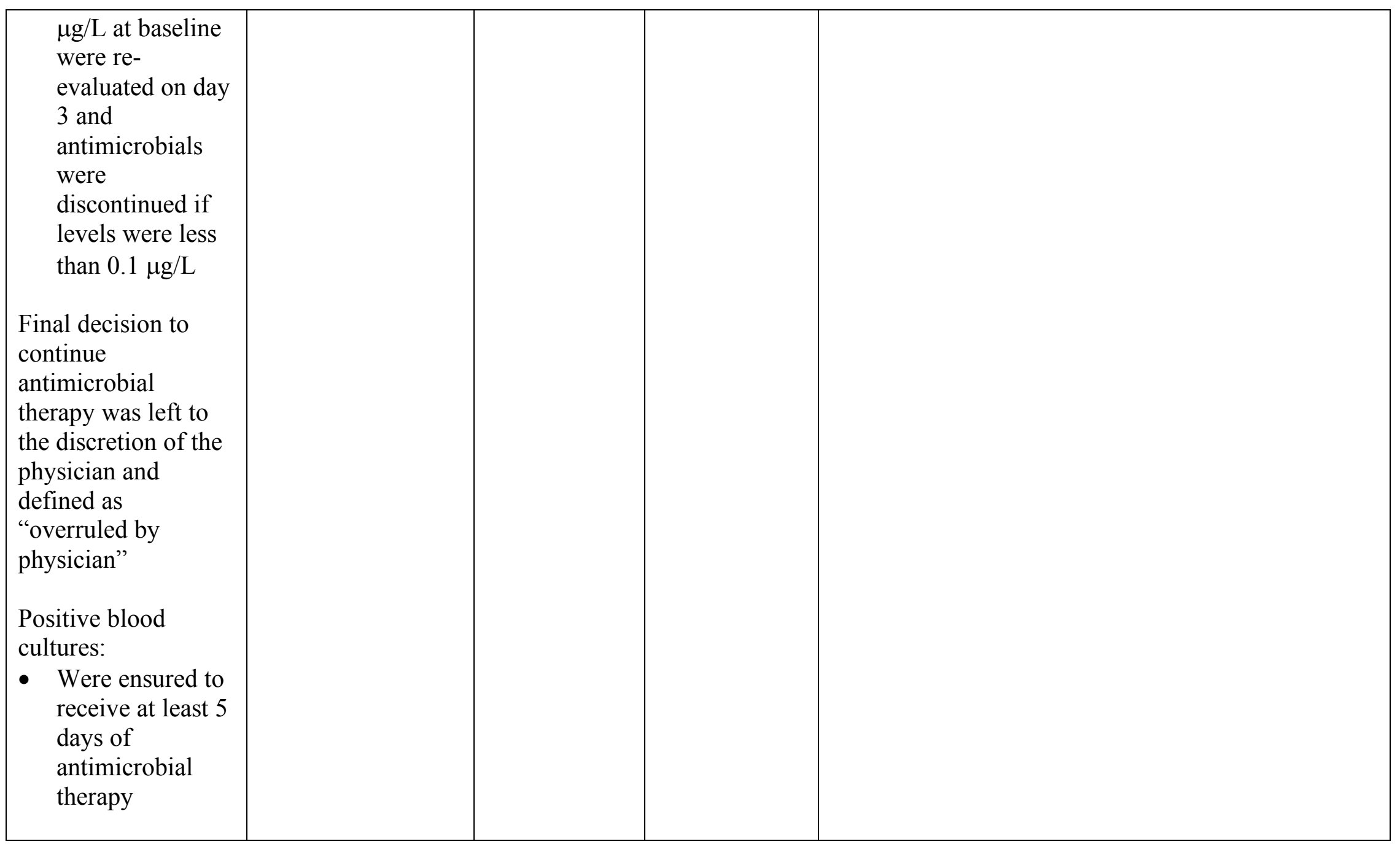




\section{Appendix B-2}

\section{Data Collection Tool 2}

Schroeder, S., Hochreiter, M., Koehler, T., Schweiger, A.M., Bein, B., Keck, F. S., \& von Spiegel, T. (2008). Procalcitonin (PCT)guided algorithm reduces length of antibiotic treatment in surgical intensive care patients with severe sepsis: results of a prospective randomized study. Lagenbecks Archives of Surgery, 394, 221-226. http://dx.doi.org/10.1007/s00423-008-0432-1

\begin{tabular}{|c|c|c|c|c|c|c|c|}
\hline \multicolumn{2}{|c|}{ Treatment Methods } & \multicolumn{2}{|c|}{$\begin{array}{l}\text { Total Days Receiving } \\
\text { Antimicrobials }\end{array}$} & \multicolumn{4}{|c|}{ Results } \\
\hline $\begin{array}{l}\text { Intervention } \\
\text { Group }\end{array}$ & Control Group & $\begin{array}{l}\text { Intervention } \\
\text { Group }\end{array}$ & Control Group & & & & \\
\hline \multicolumn{2}{|c|}{$\begin{array}{l}\text { Daily standard labs included C- } \\
\text { Reactive Protein }\end{array}$} & $\begin{array}{l}\text { Duration of } \\
\text { antimicrobial }\end{array}$ & $\begin{array}{l}\text { Duration of } \\
\text { antimicrobial }\end{array}$ & \multicolumn{4}{|l|}{ Diagnoses: } \\
\hline \multirow{2}{*}{$\begin{array}{l}\text { Procalcitonin } \\
\text { measured }\end{array}$} & \multirow{9}{*}{$\begin{array}{l}\text { Antimicrobial } \\
\text { therapy } \\
\text { discontinuation } \\
\text { occurred } \\
\text { according to } \\
\text { clinical signs and } \\
\text { empiric rules }\end{array}$} & therapy, mean & therapy, mean & \multicolumn{3}{|c|}{ Peritonitis } & \\
\hline & & $\begin{array}{l}\text { days/standard } \\
\text { deviation }\end{array}$ & $\begin{array}{l}\text { days/standard } \\
\text { deviation }\end{array}$ & Control group & Interven & n group & \\
\hline \multirow{7}{*}{$\begin{array}{l}\text { Antimicrobial } \\
\text { therapy } \\
\text { discontinuation } \\
\text { occurred once the } \\
\text { following criteria } \\
\text { was met: } \\
\text { - Clinical signs } \\
\text { and symptoms } \\
\text { of sepsis } \\
\text { improved }\end{array}$} & & - $\quad 6.6 \pm 1.1$ & - $8.3 \pm 0.7$ & 9 & & & \\
\hline & & - $P=0.001$ & - $P=0.001$ & \multicolumn{3}{|c|}{ Pneumonia } & \\
\hline & & & & 4 & \multicolumn{2}{|c|}{4} & \\
\hline & & & & \multicolumn{4}{|c|}{$\begin{array}{l}\text { Underlying pathology for peritonitis with percentage } \\
\text { of population: }\end{array}$} \\
\hline & & & & \multirow{2}{*}{\multicolumn{2}{|c|}{\begin{tabular}{|l|} 
Colonic-sigmoid perforation \\
Anastomotic leakage
\end{tabular}}} & $28 \%$ & \\
\hline & & & & & & $21 \%$ & \\
\hline & & & & \multicolumn{2}{|c|}{ Transmigration peritonitis } & $15 \%$ & \\
\hline
\end{tabular}


- Procalcitonin levels decreased to $1 \mathrm{ng} / \mathrm{L}$ or a drop of 25$35 \%$ from the initial procalcitonin levels over three consecutive days

- The physician was free to continue antimicrobials based upon clinical judgement

\begin{tabular}{|l|c|}
\hline Small bowel perforation & $11 \%$ \\
\hline Gastric perforation & $15 \%$ \\
\hline Gallbladder perforation & $5 \%$ \\
\hline Tubo-ovarian abscess & $5 \%$ \\
\hline
\end{tabular}

ICU Days: mean/standard deviation

\begin{tabular}{|c|c|}
\hline Control group & Intervention group \\
\hline $16.7 \pm 5.6$ & $16.4 \pm 8.3$ \\
\hline
\end{tabular}




\section{Appendix B-3}

\section{Collection Tool 2}

Annane, D., Maxime, V., Faller, J. P., Mezher, C., Flech, C., Martel, P., ... Nardi, O. (2013). Procalcitonin levels to guide antibiotiv therapy in adults with non-microbiologically proven apparent severe sepsis: A randomized controlled trial. BMJ Open, 3, 1-7. http://dx.doi.org/10.1136/bmjopen-2012-002186

\begin{tabular}{|c|c|c|c|c|c|c|}
\hline \multicolumn{2}{|c|}{ Treatment Methods } & \multicolumn{2}{|c|}{$\begin{array}{l}\text { Total Days Receiving } \\
\text { Antimicrobials }\end{array}$} & \multirow{2}{*}{\multicolumn{3}{|c|}{ Results }} \\
\hline Intervention Group & $\begin{array}{l}\text { Control } \\
\text { Group }\end{array}$ & $\begin{array}{l}\text { Intervention } \\
\text { Group }\end{array}$ & $\begin{array}{l}\text { Control } \\
\text { Group }\end{array}$ & & & \\
\hline \multirow{3}{*}{$\begin{array}{l}\text { Initiation and } \\
\text { discontinuation of } \\
\text { antimicrobials was } \\
\text { guided by a } \\
\text { procalcitonin based } \\
\text { algorithm. }\end{array}$} & \multirow{9}{*}{$\begin{array}{l}\text { Decision to } \\
\text { start or stop } \\
\text { antimicrobials } \\
\text { was at the } \\
\text { discretion of } \\
\text { the physician } \\
\text { without } \\
\text { knowing the } \\
\text { procalcitonin } \\
\text { level. }\end{array}$} & \multicolumn{2}{|c|}{$\begin{array}{c}\text { Number of patients on } \\
\text { antimicrobial therapy at } \\
\text { Day } 5 \mathrm{P}=0.24\end{array}$} & \multicolumn{2}{|r|}{ Day 5} & \\
\hline & & $\begin{array}{l}\text { Survivors } \\
\text { only }\end{array}$ & $\begin{array}{l}\text { Survivors } \\
\text { only }\end{array}$ & \multicolumn{2}{|c|}{ Intervention Group } & $\begin{array}{l}\text { Control } \\
\text { Group }\end{array}$ \\
\hline & & - $18(67 \%)$ & - 21 & \multicolumn{2}{|c|}{ 3/31 (10\%) } & $3 / 31(10 \%)$ \\
\hline \multirow{6}{*}{$\begin{array}{l}\text { Procalcitonin levels } \\
\text { drawn at the following } \\
\text { intervals: } \\
\text { - } 6 \text { hours } \\
\text { - Day } 3 \\
\text { - Day } 5\end{array}$} & & & & \multicolumn{3}{|c|}{ ICU discharge } \\
\hline & & & & \multicolumn{2}{|c|}{$7 / 31(23 \%)$} & $10 / 30(33 \%)$ \\
\hline & & & & \multicolumn{3}{|c|}{ Hospital Discharge } \\
\hline & & & & \multicolumn{2}{|c|}{ ICU } & \multirow[t]{3}{*}{$10 / 30(33 \%)$} \\
\hline & & & & $\begin{array}{l}\text { Intervention } \\
\text { Group }\end{array}$ & Control Group & \\
\hline & & & & $22(8-42)$ & $23(10-60)$ & \\
\hline
\end{tabular}


Antimicrobial therapy recommendations based on procalcitonin levels:

- $<0.25 \mu \mathrm{g} / \mathrm{L}$ : antimicrobials halted and not recommended to be started

- $\geq 0.25 \mu \mathrm{g} / \mathrm{L}$ $<0.5 \mu \mathrm{g} / \mathrm{L}$ :

antimicrobials were strongly discouraged

- $\quad \geq 0.5 \mu \mathrm{g} / \mathrm{L}<5 \mu \mathrm{g} / \mathrm{L}$ : antimicrobials recommended

- $\quad \geq 5 \mu \mathrm{g} / \mathrm{L}$ :

antimicrobials strongly

recommended

- Investigators were asked not to overrule the algorithm every day up to Day 5

\begin{tabular}{|c|c|}
\hline \multicolumn{2}{|c|}{ Hospital } \\
\hline $27(9-49)$ & $33(11-69)$ \\
\hline
\end{tabular}

Mortality:

Length of stay (days) 


\section{Appendix B-4}

Data Collection Tool 2

Bishop, B.M., Bon, J. J., Trienski, T. L., Pasquale, T.R., Martin, B.R., \& File Jr, T.M. (2014). Effect of introducing procalcitonin on antimicrobial therapy duration in patients with sepsis and/or pneumonia in the intensive care unit. Annals of Pharmocotherapy, 48(5), 577-583. http://dx.doi.org/10.1177/1060028014520957

\begin{tabular}{|c|c|c|c|c|}
\hline Treatment Methods & $\begin{array}{l}\text { Total Day } \\
\text { Antimi }\end{array}$ & $\begin{array}{l}\text { Receiving } \\
\text { robials }\end{array}$ & & \\
\hline Intervention Group & $\begin{array}{l}\text { Intervention } \\
\text { Group }\end{array}$ & $\begin{array}{l}\text { Control } \\
\text { Group }\end{array}$ & & \\
\hline $\begin{array}{l}\text { This was a prospective, observational } \\
\text { study. Procalcitonin levels became }\end{array}$ & $\begin{array}{r}\text { Total days of } \\
\text { therapy } \mathrm{F}\end{array}$ & $\begin{array}{l}\text { timicrobial } \\
0.0238\end{array}$ & Length & pital $P=0.0299$ \\
\hline $\begin{array}{l}\text { algorithm was included with } \\
\text { recommendations for antimicrobial }\end{array}$ & $10( \pm 4.9)$ & $13.3( \pm 7.2)$ & $\begin{array}{l}\text { Intervention } \\
\text { Group }\end{array}$ & Control Group \\
\hline therapy & & & $13.5( \pm 6.6)$ & $17.8( \pm 11)$ \\
\hline Procalcitonin levels: & & & Leng & $\mathrm{CU} P=0.0767$ \\
\hline - Baseline procalcitonin level & & & $8.4( \pm 5.8)$ & $12( \pm 9.7)$ \\
\hline admission to the ICU or was in the & & & & ity $\mathrm{P}=0.5$ \\
\hline $\begin{array}{l}\text { ICU with newly suspected infectious } \\
\text { process of pneumonia and/or sepsis }\end{array}$ & & & $1(2 \%)$ & $2(4 \%)$ \\
\hline
\end{tabular}


- Received 1 follow-up procalcitonin measurement at least 48 hours after initial level

Antimicrobial recommendations based on procalcitonin algorithm for lower respiratory tract infections

Group A: Initial Procalcitonin Levels

- $\quad<0.1 \mu \mathrm{g} / \mathrm{L}$ : antimicrobial initialization strongly discouraged

- $0.1 \mu \mathrm{g} / \mathrm{L}-0.24 \mu \mathrm{g} / \mathrm{L}$ : initiation discouraged

- $\quad \geq 0.25 \mu \mathrm{g} / \mathrm{L}-0.5 \mu \mathrm{g} / \mathrm{L}$ : Initiation encouraged

○ Repeat procalcitonin every 48 hours to consider early antimicrobial discontinuation

- $>0.5 \mu \mathrm{g} / \mathrm{L}$ : Initiation strongly encouraged

- Repeat procalcitonin level every 48 hours to consider early antimicrobial discontinuation

Group B: Follow up procalcitonin levels

- $<0.1 \mu \mathrm{g} / \mathrm{L}$ or drop by $>90 \%$ : discontinuation of antimicrobials strongly encouraged 
- $0.1 \mu \mathrm{g} / \mathrm{L}-0.24 \mu \mathrm{g} / \mathrm{L}$ or drop by $>80 \%$ : discontinuation of antimicrobials encouraged

- $\quad \geq 0.25 \mu \mathrm{g} / \mathrm{L}-0.5 \mu \mathrm{g} / \mathrm{L}$ : discontinuation of antimicrobials discouraged

- $>0.5 \mu \mathrm{g} / \mathrm{L}$ : discontinuation of antimicrobials strongly discouraged

Sepsis procalcitonin algorithm

Group A: initial procalcitonin levels

- $<0.25 \mu \mathrm{g} / \mathrm{L}$ : antimicrobial initiation strongly discouraged

- $\quad 0.25 \mu \mathrm{g} / \mathrm{L}-0.49 \mu \mathrm{g} / \mathrm{L}$ : antimicrobial initiation discouraged

- $\quad \geq 0.5 \mu \mathrm{g} / \mathrm{L}-1.0 \mu \mathrm{g} / \mathrm{L}$ : antimicrobial initiation encouraged

- $>1.0 \mu \mathrm{g} / \mathrm{L}$ : antimicrobial initiation strongly encouraged

Group B: follow up procalcitonin levels

- $<0.25 \mu \mathrm{g} / \mathrm{L}$ : antimicrobial discontinuation strongly encouraged

- $0.25 \mu \mathrm{g} / \mathrm{L}-0.49 \mu \mathrm{g} / \mathrm{L}$ or drop by $80 \%$ : antimicrobial discontinuation encouraged

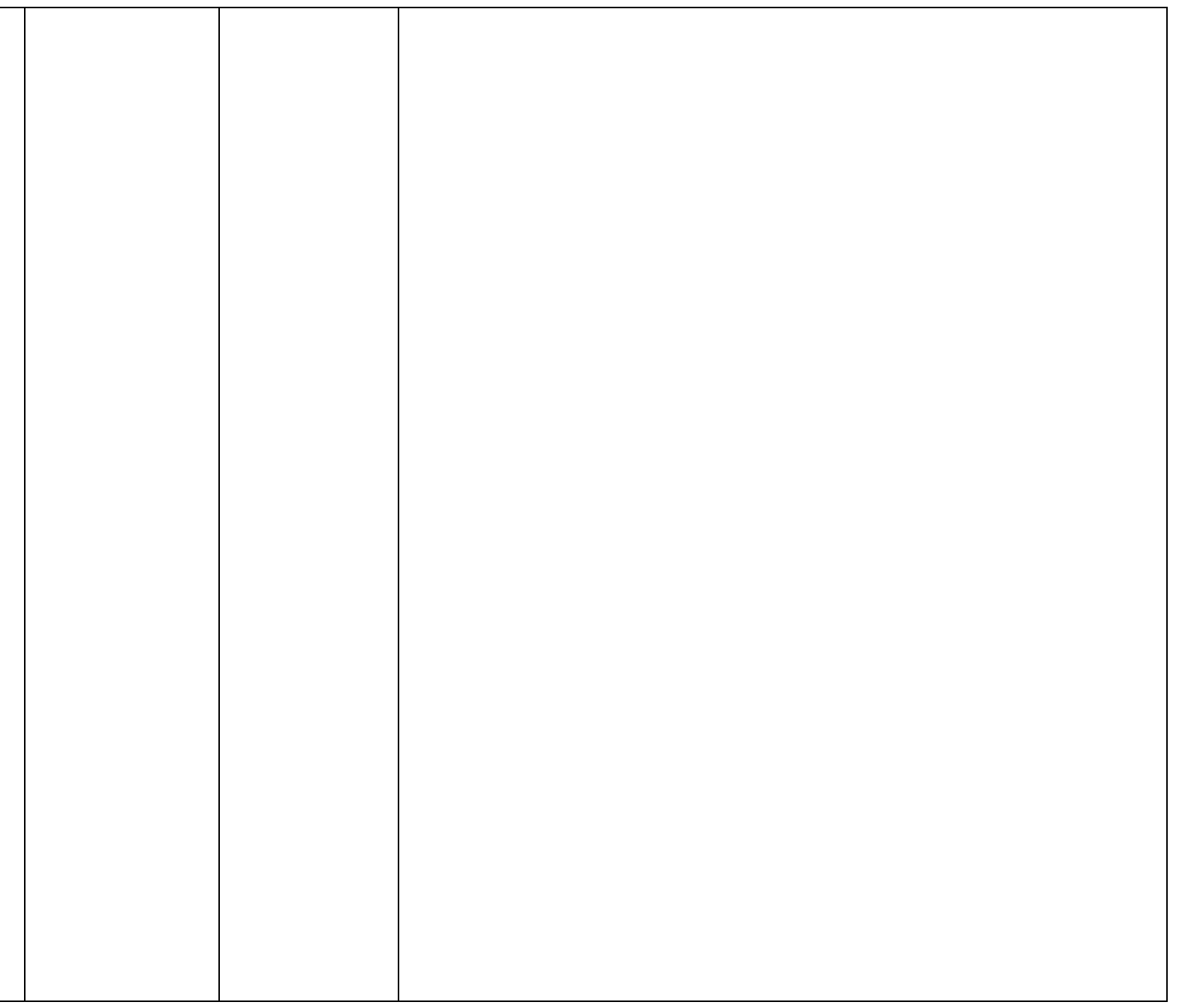


- $\quad \geq 0.5 \mu \mathrm{g} / \mathrm{L}$ and drop by $80 \%$ : antimicrobial discontinuation discouraged

- $\geq 0.5 \mu \mathrm{g} / \mathrm{L}$ and rising or not decreasing: antimicrobial discontinuation strongly discouraged 


\section{Appendix B-5}

\section{Data Collection Tool 2}

Shehabi, Y., Sterba, M., Garrett, P. M., Rachakonda, K. S., Stephens, D., Harrigan, P., ... Fraser, J. F. (2014). Procalcitonin algorithm in critically ill adults with undifferentiated infection or suspected sepsis: a randomized controlled trial. American Journal of Respiratory and Critical Care Medicine, 190(10), 1102-1110. http://dx.doi.org/10.1164/rccm.201408-1483OC

\begin{tabular}{|c|c|c|c|c|c|}
\hline \multicolumn{2}{|c|}{ Treatment Methods } & \multicolumn{2}{|c|}{ Total Days Receiving Antimicrobials } & \multicolumn{2}{|c|}{ Results } \\
\hline Intervention Group & Control Group & $\begin{array}{l}\text { Intervention } \\
\text { Group }\end{array}$ & Control Group & & \\
\hline \multirow{3}{*}{\multicolumn{2}{|c|}{$\begin{array}{l}\text { Procalcitonin levels were measured on } \\
\text { all patients at randomization and daily } \\
\text { thereafter until ICU discharge or up to } 7 \\
\text { days, whichever came first. }\end{array}$}} & \multirow{3}{*}{\multicolumn{2}{|c|}{$\begin{array}{l}\text { Median days of time to antimicrobial } \\
\text { discontinuation } \mathrm{P}=0.58\end{array}$}} & \multicolumn{2}{|c|}{ ICU Length of Stay (Median) $\mathrm{P}=0.87$} \\
\hline & & & & $\begin{array}{c}\text { Intervention } \\
\text { Group }\end{array}$ & Control Group \\
\hline & & & & $6(3-9.5)$ & $6(4-10)$ \\
\hline \multirow{3}{*}{$\begin{array}{l}\text { Procalcitonin } \\
\text { levels were made } \\
\text { available to } \\
\text { treating physician. }\end{array}$} & \multirow{8}{*}{$\begin{array}{l}\text { Procalcitonin } \\
\text { levels were faxed } \\
\text { directly to the } \\
\text { Clinical } \\
\text { Informatics and } \\
\text { Data Management } \\
\text { Unit and not made } \\
\text { available to } \\
\text { treating } \\
\text { physicians. }\end{array}$} & \multirow[t]{8}{*}{$9(6-20)$} & \multirow[t]{8}{*}{$11(6-22)$} & Hospital Lengt & (Median) $\mathrm{P}=0.19$ \\
\hline & & & & $15(9-29)$ & $17(10-32)$ \\
\hline & & & & & ality \\
\hline \multirow{5}{*}{$\begin{array}{l}\text { Procalcitonin } \\
\text { algorithm: treating } \\
\text { physicians had the } \\
\text { option to overrule } \\
\text { the algorithm as } \\
\text { clinically } \\
\text { indicated. }\end{array}$} & & & & $21(11 \%)$ & $15(8 \%)$ \\
\hline & & & & \multicolumn{2}{|c|}{ Hospital Mortality } \\
\hline & & & & $30(16 \%)$ & $26(13 \%)$ \\
\hline & & & & \multicolumn{2}{|c|}{90 Day all-cause Mortality } \\
\hline & & & & $35(18 \%)$ & $31(16 \%)$ \\
\hline
\end{tabular}




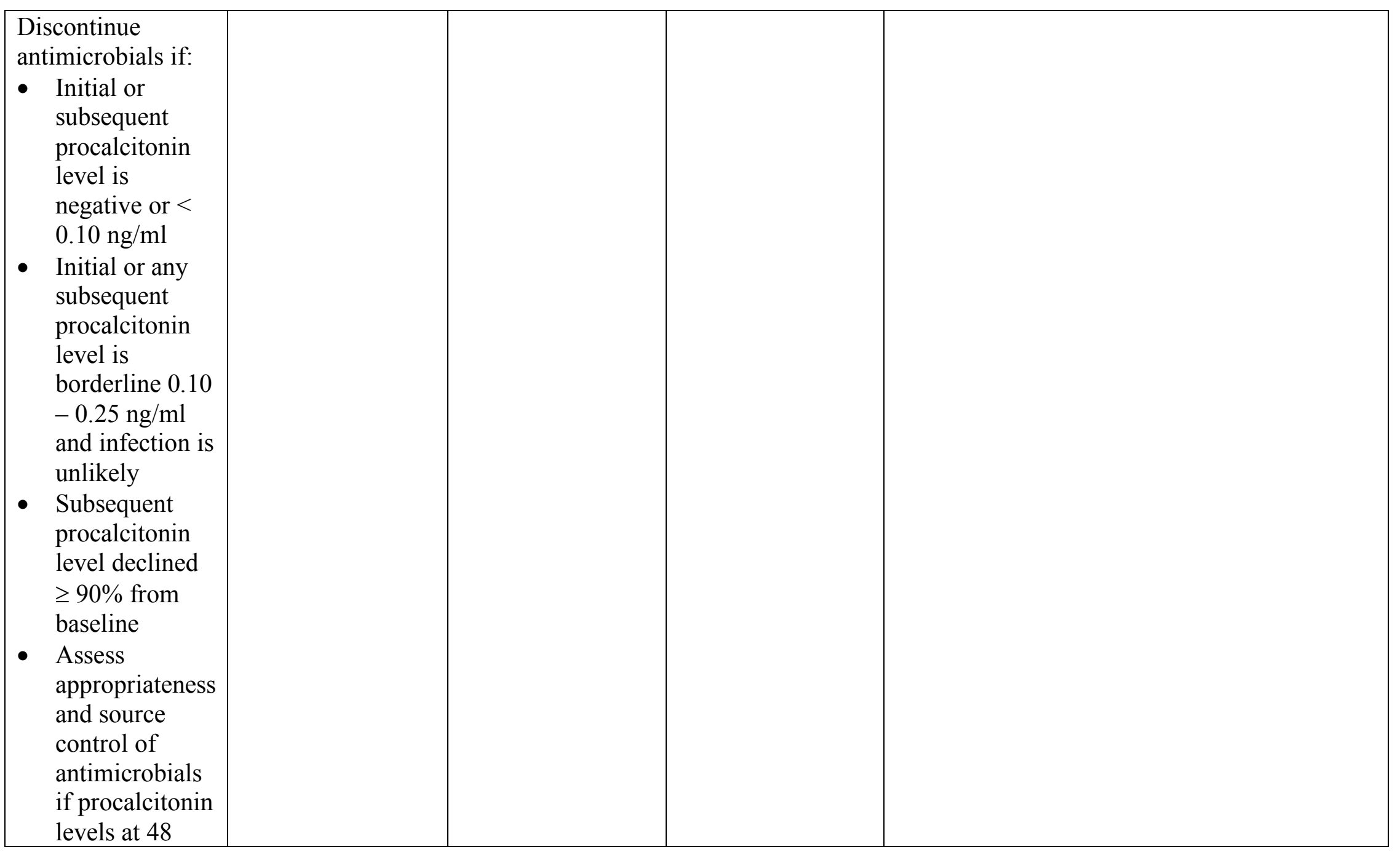


hours $>70 \%$ of baseline value 


\section{Appendix C-1}

Critical Appraisal Skills Program

Nobre, V., Harbarth, S., Graf, J., Rohner, P., \& Pugin, J. (2008). Use of procalcitonin to shorten antibiotic treatment duration in septic patients: a randomized trial. American Journal of Respiratory and Critical Care Medicine, 177, 498-505: http://doi.org/10.1164/rccm.200708-12380C

\begin{tabular}{|c|c|c|c|c|}
\hline \multicolumn{5}{|c|}{ Section A: Are the results of the trial valid? } \\
\hline 1 & Did the trial address a clearly focused issue? & Yes & Can't Tell & No \\
\hline 2 & $\begin{array}{l}\text { Was the assignment of patients to treatments } \\
\text { randomized }\end{array}$ & Yes & Can’t Tell & No \\
\hline 3 & $\begin{array}{l}\text { Were all of the patients who entered the trial } \\
\text { properly accounted for at its conclusion }\end{array}$ & Yes & Can’t Tell & No \\
\hline \multicolumn{5}{|c|}{ Is it worth continuing? } \\
\hline 4 & $\begin{array}{l}\text { Were patients, health workers, and study } \\
\text { personnel "blind" to treatment }\end{array}$ & Yes & Can’t Tell & No \\
\hline 5 & $\begin{array}{l}\text { Were the groups similar at the start of the } \\
\text { trial }\end{array}$ & Yes & Can’t Tell & No \\
\hline 6 & $\begin{array}{l}\text { Aside from the experimental intervention, } \\
\text { were the groups treated equally? }\end{array}$ & Yes & Can’t Tell & No \\
\hline \multicolumn{5}{|c|}{ Section B: What are the results? } \\
\hline 7 & How large was the treatment effect? & \multicolumn{3}{|c|}{$\begin{array}{l}\text { The median days receiving antimicrobial therapy: control group }-9.5 / \\
\text { Intervention group }-6(p=0.15)\end{array}$} \\
\hline 8 & $\begin{array}{l}\text { How precise was the estimate of the } \\
\text { treatment effect? }\end{array}$ & \multicolumn{3}{|c|}{$\begin{array}{l}\text { Total antimicrobial exposure days were lower in the procalcitonin group } \\
\text { compared with the control group }\{504 \text { vs } 655 \text { days, incidence rate ratio (IRR) } \\
1.1 ; 95 \% \text { Confidence Interval }(\mathrm{CI}), \mathrm{P}=0.07\}\end{array}$} \\
\hline
\end{tabular}




\begin{tabular}{|c|c|c|c|c|}
\hline 9 & $\begin{array}{l}\text { Can the results be applied to the local } \\
\text { population, or in your context? }\end{array}$ & Yes & Can't Tell & No \\
\hline 10 & $\begin{array}{l}\text { Were all clinically important outcomes } \\
\text { considered? }\end{array}$ & Yes & Can't Tell & No \\
\hline 11 & Are the benefits worth the harms and costs? & Yes & Can't Tell & No \\
\hline
\end{tabular}




\section{Appendix C-2}

Critical Appraisal Skills Program

Schroeder, S., Hochreiter, M., Koehler, T., Schweiger, A.M., Bein, B., Keck, F. S., \& von Spiegel, T. (2008). Procalcitonin (PCT)guided algorithm reduces length of antibiotic treatment in surgical intensive care patients with severe sepsis: results of a prospective randomized study. Lagenbecks Archives of Surgery, 394, 221-226. http://dx.doi.org/10.1007/s00423-008-0432-1

\begin{tabular}{|c|c|c|c|c|}
\hline \multicolumn{5}{|c|}{ Section A: Are the results of the trial valid? } \\
\hline 1 & Did the trial address a clearly focused issue? & Yes & Can't Tell & No \\
\hline 2 & $\begin{array}{l}\text { Was the assignment of patients to treatments } \\
\text { randomized }\end{array}$ & Yes & Can't Tell & No \\
\hline 3 & $\begin{array}{l}\text { Were all of the patients who entered the trial } \\
\text { properly accounted for at its conclusion }\end{array}$ & Yes & Can’t Tell & No \\
\hline \multicolumn{5}{|c|}{ Is it worth continuing? } \\
\hline 4 & $\begin{array}{l}\text { Were patients, health workers, and study } \\
\text { personnel "blind" to treatment }\end{array}$ & Yes & Can't Tell & No \\
\hline 5 & $\begin{array}{l}\text { Were the groups similar at the start of the } \\
\text { trial }\end{array}$ & Yes & Can’t Tell & No \\
\hline 6 & $\begin{array}{l}\text { Aside from the experimental intervention, } \\
\text { were the groups treated equally? }\end{array}$ & Yes & Can’t Tell & No \\
\hline \multicolumn{5}{|c|}{ Section B: What are the results? } \\
\hline 7 & How large was the treatment effect? & \multicolumn{3}{|c|}{$\begin{array}{l}\text { The mean days of receiving antimicrobials were } 6.6 \text { in the procalcitonin guided } \\
\text { group vs } 8.3 \text { in the control group }(\mathrm{p}=<0.001)\end{array}$} \\
\hline 8 & $\begin{array}{l}\text { How precise was the estimate of the } \\
\text { treatment effect? }\end{array}$ & \multicolumn{3}{|c|}{$\begin{array}{l}\text { Statistical analysis conducted using the Mann-Whitney } U \text { test and differences } \\
\text { were analyzed by using the chi-square test }\end{array}$} \\
\hline 9 & $\begin{array}{l}\text { Can the results be applied to the local } \\
\text { population, or in your context? }\end{array}$ & Yes & Can't Tell & No \\
\hline
\end{tabular}




\begin{tabular}{|c|l|c|c|c|}
\hline 10 & $\begin{array}{l}\text { Were all clinically important outcomes } \\
\text { considered? }\end{array}$ & Yes & Nan't Tell \\
\hline 11 & Are the benefits worth the harms and costs? & Yes & Can't Tell & No \\
\hline
\end{tabular}




\section{Appendix C-3}

Critical Appraisal Skills Program

Annane, D., Maxime, V., Faller, J. P., Mezher, C., Flech, C., Martel, P., ... Nardi, O. (2013). Procalcitonin levels to guide antibiotiv therapy in adults with non-microbiologically proven apparent severe sepsis: A randomized controlled trial. BMJ Open, 3, 1-7. http://dx.doi.org/10.1136/bmjopen-2012-002186

\begin{tabular}{|c|c|c|c|c|}
\hline \multicolumn{5}{|c|}{ Section A: Are the results of the trial valid? } \\
\hline 1 & Did the trial address a clearly focused issue? & Yes & Can't Tell & No \\
\hline 2 & $\begin{array}{l}\text { Was the assignment of patients to treatments } \\
\text { randomized }\end{array}$ & Yes & Can't Tell & No \\
\hline 3 & $\begin{array}{l}\text { Were all of the patients who entered the trial } \\
\text { properly accounted for at its conclusion }\end{array}$ & Yes & Can't Tell & No \\
\hline \multicolumn{5}{|c|}{ Is it worth continuing? } \\
\hline 4 & $\begin{array}{l}\text { Were patients, health workers, and study } \\
\text { personnel "blind" to treatment }\end{array}$ & Yes & Can't Tell & No \\
\hline 5 & $\begin{array}{l}\text { Were the groups similar at the start of the } \\
\text { trial }\end{array}$ & Yes & Can't Tell & No \\
\hline 6 & $\begin{array}{l}\text { Aside from the experimental intervention, } \\
\text { were the groups treated equally? }\end{array}$ & Yes & Can't Tell & No \\
\hline \multicolumn{5}{|c|}{ Section B: What are the results? } \\
\hline 7 & How large was the treatment effect? & \multicolumn{3}{|c|}{$\begin{array}{l}\text { At Day } 5 \text { post-randomization, } 67 \% \text { of the intervention and } 81 \% \text { of the control } \\
\text { group was receiving antimicrobials }\end{array}$} \\
\hline 8 & $\begin{array}{l}\text { How precise was the estimate of the } \\
\text { treatment effect? }\end{array}$ & \multicolumn{3}{|c|}{$\begin{array}{l}\text { At Day } 5 \text { post-randomization, the intervention group } 18 / 27 \text { vs } 21 / 26 \text { patients in } \\
\text { the control group receiving antimicrobials }(95 \% \text { CI, relative risk }(R R)=0.83, p \\
=0.24)\end{array}$} \\
\hline
\end{tabular}




\begin{tabular}{|c|c|c|c|c|}
\hline 9 & $\begin{array}{l}\text { Can the results be applied to the local } \\
\text { population, or in your context? }\end{array}$ & Yes & Can't Tell & No \\
\hline 10 & $\begin{array}{l}\text { Were all clinically important outcomes } \\
\text { considered? }\end{array}$ & Yes & Can't Tell & No \\
\hline 11 & Are the benefits worth the harms and costs? & Yes & Can't Tell & No \\
\hline
\end{tabular}




\section{Appendix C-4}

Critical Appraisal Skills Program

Bishop, B.M., Bon, J. J., Trienski, T. L., Pasquale, T.R., Martin, B.R., \& File Jr, T.M. (2014). Effect of introducing procalcitonin on antimicrobial therapy duration in patients with sepsis and/or pneumonia in the intensive care unit. Annals of Pharmocotherapy, 48(5), 577-583. http://dx.doi.org/10.1177/1060028014520957

\begin{tabular}{|c|c|c|c|c|}
\hline \multicolumn{5}{|c|}{ Section A: Are the results of the trial valid? } \\
\hline 1 & Did the trial address a clearly focused issue? & Yes & Can't Tell & No \\
\hline 2 & $\begin{array}{l}\text { Was the assignment of patients to treatments } \\
\text { randomized }\end{array}$ & Yes & Can't Tell & No \\
\hline 3 & $\begin{array}{l}\text { Were all of the patients who entered the trial } \\
\text { properly accounted for at its conclusion }\end{array}$ & Yes & Can't Tell & No \\
\hline \multicolumn{5}{|c|}{ Is it worth continuing? } \\
\hline 4 & $\begin{array}{l}\text { Were patients, health workers, and study } \\
\text { personnel "blind" to treatment }\end{array}$ & Yes & Can't Tell & No \\
\hline 5 & $\begin{array}{l}\text { Were the groups similar at the start of the } \\
\text { trial }\end{array}$ & Yes & Can't Tell & No \\
\hline 6 & $\begin{array}{l}\text { Aside from the experimental intervention, } \\
\text { were the groups treated equally? }\end{array}$ & Yes & Can't Tell & No \\
\hline \multicolumn{5}{|c|}{ Section B: What are the results? } \\
\hline 7 & How large was the treatment effect? & \multicolumn{3}{|c|}{$\begin{array}{l}\text { The average days of receiving antimicrobial therapy were } 10 \text { in the } \\
\text { procalcitonin group vs } 13.3(95 \% \mathrm{CI}=0.9-5.76 ; \mathrm{p}=0.0238)\end{array}$} \\
\hline 8 & $\begin{array}{l}\text { How precise was the estimate of the } \\
\text { treatment effect? }\end{array}$ & \multicolumn{3}{|c|}{$\begin{array}{l}\text { The Wilcoxon-Mann Whitney test was used to evaluate the difference in the } \\
\text { duration of antimicrobial therapy. The Anderson-Darling test was used to test } \\
\text { for data normality. }\end{array}$} \\
\hline
\end{tabular}




\begin{tabular}{|c|l|c|c|c|}
\hline 9 & $\begin{array}{l}\text { Can the results be applied to the local } \\
\text { population, or in your context? }\end{array}$ & Yes & Can't Tell \\
\hline 10 & $\begin{array}{l}\text { Were all clinically important outcomes } \\
\text { considered? }\end{array}$ & Yes & Can't Tell & No \\
\hline 11 & Are the benefits worth the harms and costs? & Yes & Can't Tell & No \\
\hline
\end{tabular}




\section{Appendix C-5}

Critical Appraisal Skills Program

Shehabi, Y., Sterba, M., Garrett, P. M., Rachakonda, K. S., Stephens, D., Harrigan, P., ... Fraser, J. F. (2014). Procalcitonin algorithm in critically ill adults with undifferentiated infection or suspected sepsis: a randomized controlled trial. American Journal of Respiratory and Critical Care Medicine, 190(10), 1102-1110. http://dx.doi.org/10.1164/rccm.201408-1483OC

\begin{tabular}{|c|c|c|c|c|}
\hline \multicolumn{5}{|c|}{ Section A: Are the results of the trial valid? } \\
\hline 1 & Did the trial address a clearly focused issue? & Yes & Can't Tell & No \\
\hline 2 & $\begin{array}{l}\text { Was the assignment of patients to treatments } \\
\text { randomized }\end{array}$ & Yes & Can't Tell & No \\
\hline 3 & $\begin{array}{l}\text { Were all of the patients who entered the trial } \\
\text { properly accounted for at its conclusion }\end{array}$ & Yes & Can't Tell & No \\
\hline \multicolumn{5}{|c|}{ Is it worth continuing? } \\
\hline 4 & $\begin{array}{l}\text { Were patients, health workers, and study } \\
\text { personnel "blind" to treatment }\end{array}$ & Yes & Can't Tell & No \\
\hline 5 & $\begin{array}{l}\text { Were the groups similar at the start of the } \\
\text { trial }\end{array}$ & Yes & Can't Tell & No \\
\hline 6 & $\begin{array}{l}\text { Aside from the experimental intervention, } \\
\text { were the groups treated equally? }\end{array}$ & Yes & Can't Tell & No \\
\hline \multicolumn{5}{|c|}{ Section B: What are the results? } \\
\hline 7 & How large was the treatment effect? & \multicolumn{3}{|c|}{$\begin{array}{l}\text { Primary outcome of median days to antimicrobial cessation at } 28 \text { days. } \\
\text { Intervention group } 9 \text { days vs } 11 \text { days in the control group }(p=0.58)\end{array}$} \\
\hline 8 & $\begin{array}{l}\text { How precise was the estimate of the } \\
\text { treatment effect? }\end{array}$ & \multicolumn{3}{|c|}{$\begin{array}{l}\text { The Cox proportional hazard regression model was used to account for baseline } \\
\text { imbalances, time to antimicrobial cessation, and was adjusted for age, sex, and } \\
\text { baseline procalcitonin levels }(1.44, \mathrm{p}=0.20)\end{array}$} \\
\hline
\end{tabular}




\begin{tabular}{|c|c|c|c|c|}
\hline 9 & $\begin{array}{l}\text { Can the results be applied to the local } \\
\text { population, or in your context? }\end{array}$ & Yes & Can't Tell & No \\
\hline 10 & $\begin{array}{l}\text { Were all clinically important outcomes } \\
\text { considered? }\end{array}$ & Yes & Can't Tell & No \\
\hline 11 & Are the benefits worth the harms and costs? & Yes & Can't Tell & No \\
\hline
\end{tabular}




\section{Appendix D - 1}

Cross Study Analysis

\begin{tabular}{|c|c|c|c|c|c|c|}
\hline \multirow[t]{2}{*}{ Author/Year } & \multirow{2}{*}{\multicolumn{2}{|c|}{ Single Vs Multicenter }} & \multicolumn{2}{|c|}{$\begin{array}{c}\text { Duration of Antimicrobials } \\
\text { (median days) }\end{array}$} & \multicolumn{2}{|c|}{ Mortality } \\
\hline & & & $\begin{array}{l}\text { Intervention } \\
\text { Group }\end{array}$ & $\begin{array}{l}\text { Control } \\
\text { Group }\end{array}$ & $\begin{array}{l}\text { Intervention } \\
\text { Group }\end{array}$ & Control Group \\
\hline \multirow{3}{*}{$\begin{array}{l}\text { (Nobre, Harbarth, Graf, } \\
\text { Rohner, \& Pugin, 2008) }\end{array}$} & \multirow[t]{3}{*}{ Single } & & \multirow[t]{2}{*}{$\mathrm{N}-6$} & \multirow[t]{2}{*}{$\mathrm{N}-10$} & \multicolumn{2}{|c|}{28 - Day Mortality } \\
\hline & & & & & $\begin{array}{c}\mathrm{N}-5 \\
(16.1 \%)\end{array}$ & $\mathrm{N}-6(16.2 \%)$ \\
\hline & & & \multicolumn{2}{|c|}{$P=0.003$} & \multicolumn{2}{|c|}{$\mathrm{P}=0.74$} \\
\hline \multirow[t]{2}{*}{ (Schroeder et al., 2008) } & \multirow[t]{2}{*}{ Single } & & $\mathrm{N}-6.6$ & $\mathrm{~N}-8.3$ & \multirow{2}{*}{\multicolumn{2}{|c|}{ Not Reported }} \\
\hline & & & \multicolumn{2}{|c|}{$\mathrm{P}<0.001$} & & \\
\hline \multirow[t]{3}{*}{ (Annane et al., 2013) } & & Multicenter & \multirow[t]{2}{*}{$\mathrm{N}-5$} & \multirow[t]{2}{*}{$\mathrm{N}-5$} & \multicolumn{2}{|c|}{ Mortality at ICU Discharge } \\
\hline & & & & & $\mathrm{N}-7(23 \%)$ & $\mathrm{N}-10(33 \%)$ \\
\hline & & & \multicolumn{2}{|c|}{$\mathrm{P}=0.52$} & \multicolumn{2}{|c|}{$\mathrm{P}=0.40$} \\
\hline \multirow[t]{3}{*}{ (Bishop et al., 2014) } & \multirow[t]{3}{*}{ Single } & & $\mathrm{N}-10$ & $\mathrm{~N}-13.3$ & \multicolumn{2}{|c|}{30 Day Mortality } \\
\hline & & & \multirow{2}{*}{\multicolumn{2}{|c|}{$\mathrm{P}=0.0238$}} & $\mathrm{~N}-1(2 \%)$ & $\mathrm{N}-2(4 \%)$ \\
\hline & & & & & & $=0.5$ \\
\hline \multirow[t]{3}{*}{ (Shehabi et al., 2014) } & & Multicenter & $\mathrm{N}-9$ & $\mathrm{~N}-11$ & $90-$ Day A & Cause Mortality \\
\hline & & & \multirow{2}{*}{\multicolumn{2}{|c|}{$\mathrm{P}=0.58$}} & $\mathrm{~N}-35(18 \%)$ & $\mathrm{N}-31(16 \%)$ \\
\hline & & & & & \multicolumn{2}{|c|}{$\mathrm{P}=0.60$} \\
\hline
\end{tabular}


